Portland State University

PDXScholar

1990

\title{
Gravity maps, models and analysis of the greater Portland area, Oregon
}

Paul Thomas Beeson

Portland State University

Follow this and additional works at: https://pdxscholar.library.pdx.edu/open_access_etds

Part of the Geology Commons

Let us know how access to this document benefits you.

\section{Recommended Citation}

Beeson, Paul Thomas, "Gravity maps, models and analysis of the greater Portland area, Oregon" (1990). Dissertations and Theses. Paper 3986.

https://doi.org/10.15760/etd.5868

This Thesis is brought to you for free and open access. It has been accepted for inclusion in Dissertations and Theses by an authorized administrator of PDXScholar. Please contact us if we can make this document more accessible: pdxscholar@pdx.edu. 
AN ABSTRACT OF THE THESIS OF Paul Thomas Beeson for the degree of Master of Science in Geology presented July 6, 1990.

Title: Gravity Maps, Models and Analysis of the Greater Portland Area, Oregon.

APPROVED BY THE MEMBERS OF THE THESIS COMMITTEE:
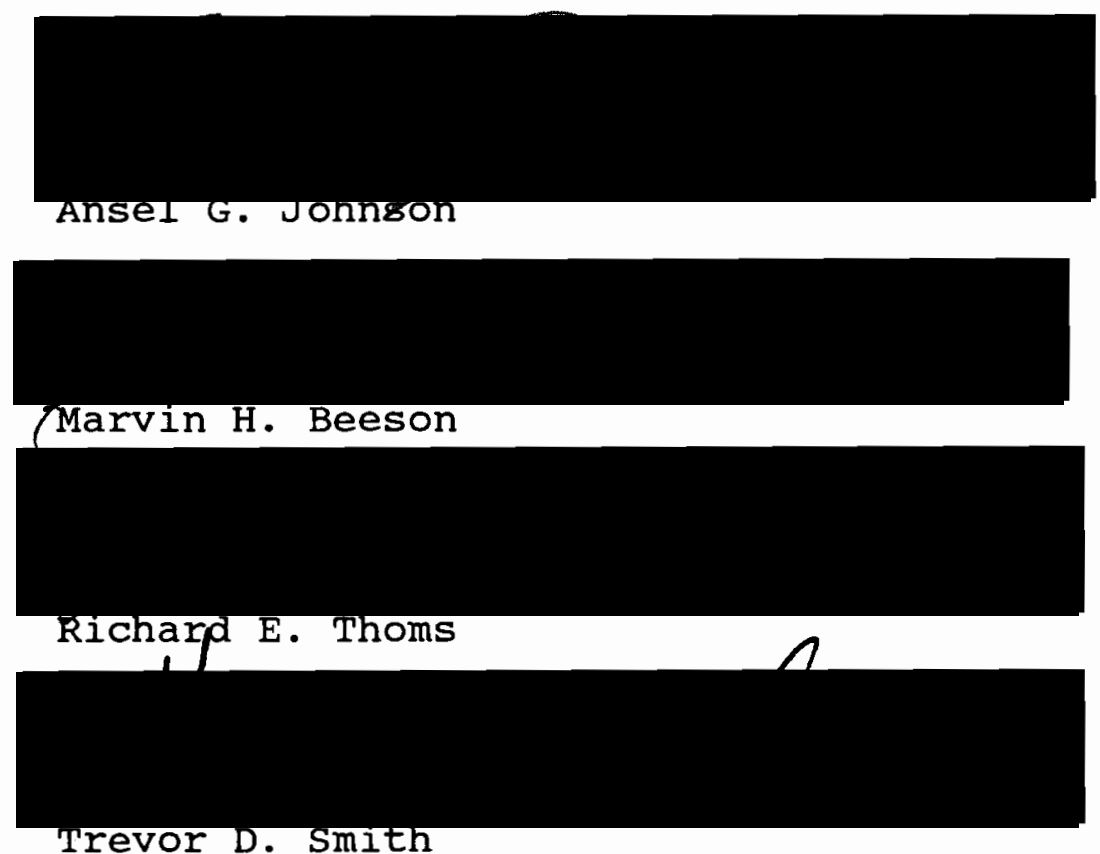

Growing concern over earthquakes in the Pacific Northwest has prompted the mapping and location of near surface faults in the Portland area, Oregon. Visible evidence of faults is poor, requiring the use of geophysical methods to assist in mapping and defining structures in the basin. Gravity maps and models may help in addressing this problem. 
Two free-air gravity models were produced. The first model constructed from existing data crosses the basin from Petes Mountain northeast to the Columbia River. The second model is from a gravity survey along Forsythe Road near Clackamas Heights.

The line crossing the basin confirms previous models which located a 320 meter, down-to-the-east offset of the Columbia River Basalt Group. This model tested and confirmed the hypothesis that the gravity high near oak Grove, Oregon was caused by an Eocene basalt high rather than an intrusive related to the Boring Lavas. Mt. Scott was modeled as a $2.87 \mathrm{~g} / \mathrm{cm}^{3}$ basalt high with a sediment filled channel along the southwest flank. The east side of the basin is modeled as faulted, confirming previous work.

The clackamas Heights line was designed to locate the Portland Hills fault but due to the depth to the fault and lack of subsurface control of the Waverly Heights basalt, the position of the fault could not be determined.

Complete Bouguer, free-air and residual Bouguer anomaly maps were produced from 1600 data stations compiled from previous gravity surveys. These maps are consistent with the state maps produced by Berg and Thiruvathukal (1967) but show more detail. The prominent features on the maps are a gravity low centered over the Tualatin Basin and a gravity high near Oak Grove, Oregon. The west edge of the maps show the high gravity north-south contours caused by the coast 
Range. The east edge of the map exhibits north-south low gravity contours caused by the cascade Mountain Range.

The Portland Basin has been called a pull-apart basin associated with wrench tectonics. This investigation supports the idea that the Portland and the Tualatin basins are related to the strike-slip motion and are formed by that motion. 
GRAVITY MAPS, MODELS AND ANALYSIS OF THE GREATER PORTLAND AREA, OREGON

\author{
by \\ PAUL T. BEESON
}

A thesis submitted in partial fulfillment of the requirements for the degree of

MASTER OF SCIENCE

in

GEOLOGY

Portland State University

1990 
TO THE OFFICE OF GRADUATE STUDIES:

The members of the committee approve the dissertation of Paul Thomas Beeson presented July 6, 1990.
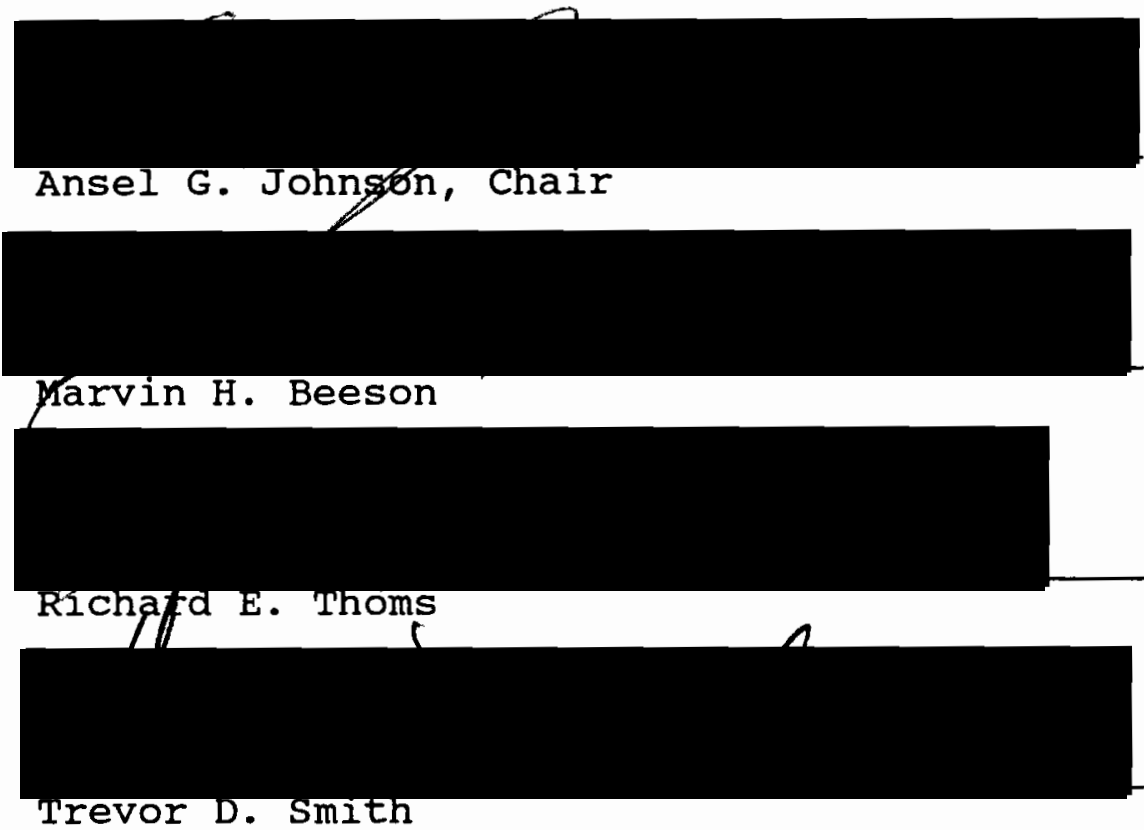

APPROVED:

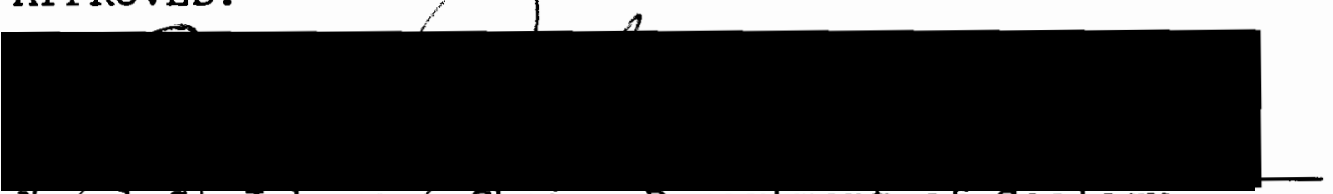

Ansel G! Johnsoy, fhair, Department of Geology

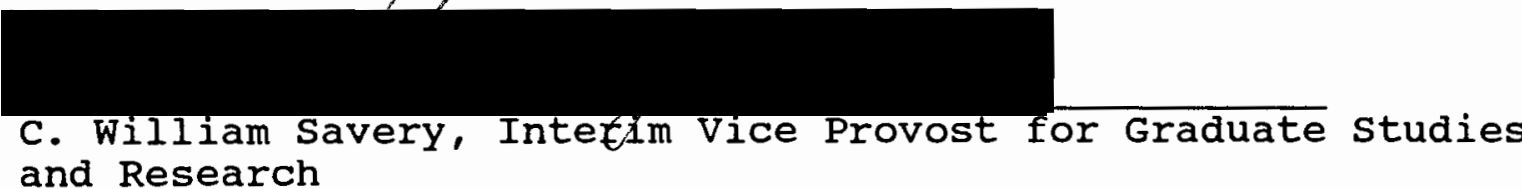
and Research 


\section{ACKNOWLEDGEMENTS}

I greatly appreciate the support provided by the faculty, staff, and fellow students of the Geology Department at Portland State University. Special thanks are given to my thesis advisor Dr. Ansel Johnson who came to me with this project and Dr. Marvin Beeson who helped me understand the geology of the Portland area.

Funding for this thesis was provided by the U.S. Geological Survey grant no. 14-08-0001-G1675 and the Oregon Department of Geology and Mineral Industries (DOGAMI). The Portland State University Geology Department also provided me with two terms of support as a Research assistant. All sources of funding were greatly appreciated.

I also thank my parents for years of encouragement and my wife Rhondasue who also provided needed support. 
TABLE OF CONTENTS

PAGE

ACKNOWLEDGEMENTS . . . . . . . . . . . . . . . iii

LIST OF TABLES . . . . . . . . . . . . . . . . . vi vi

LIST OF FIGURES . . . . . . . . . . . . . . . . . vii

INTRODUCTION . . . . . . . . . . . . . . . . . . 1

Purpose of study . . . . . . . . . . . . . . 1

Location and Extent of Study . . . . . . . . 2

Previous Work ................ 5

GEOLOGY . . . . . . . . . . . . . . . . . 8

stratigraphy . . . . . . . . . . . . 8

Introduction

Siletz River Volcanic Series

Tillamook Volcanics

Skamania Volcanic Series

Waverly Heights Basalt

Columbia River Basalt Group

Sandy River Mudstone

Troutdale Formation

Boring Lavas

Pleistocene to Recent Sediments

Structure and Tectonics ............ 17

ANALYTICAL METHODS. . . . . . . . . . . . . . 22

Data . . . . . . . . . . . . . . . 22

Introduction

Theodolite Survey

Gravity Survey

Data Reduction

Data Compilation 
GRAVITY MAPS . . . . . . . . . . . . . . . 27

Production ................. 27

Complete Bouguer Gravity Map

Residual Gravity Map

Free-air Gravity Map

GRAVITY MODELING . . . . . . . . . . . . . . 34

Introduction . . . . . . . . . . . . . . 34

Regional Model . . . . . . . . . . . . 37

Local Models . . . . . . . . . . . 39

Oak Grove Model

Clackamas Heights Model

DISCUSSION . . . . . . . . . . . . . . . 52

CONCLUSIONS . . . . . . . . . . . . . . . . 69

REFERENCES CITED . . . . . . . . . . . . . . 71

APPENDIX . . . . . . . . . . . . . . . 76 
IIST OF TABLES

TABIE

PAGE

I Modeling units . . . . . . . . . . . . 36 


\section{IIST OF FIGURES}

FIGURE

PAGE

1. Location of the study area . . . . . . . . 3

2. Location of gravity lines . . . . . . • • . 4

3. Geologic map of the Portland area from

Tolan (1989) . . . . . . . . . . . . . 9 9

4. Portland area subsurface cross-section from

Newton (1969) . . . . . . . . . . . . 12

5. Complete Bouguer gravity anomaly map of the greater Portland area, Oregon . . . . . . 29

6. Northwest corner of the state gravity map from Berg and Thiruvathukal (1967) . . . . 30

7. Residual complete Bouguer gravity anomaly map of the greater Portland area, Oregon . .

8. Free-air gravity anomaly map of the greater Portland area, Oregon with gravity station locations • . . . . . . . . . . . . 32

9. Regional gravity model . . . . . . . . 38

10. Oak Grove model and gravity profile . . . 40

11. Clackamas Heights geology and well locations from Madin (1990) . . . . . . . . . . . 45

12. Clackamas Heights regional gravity line • . 46

13. Clackamas Heights model without fault • • 48 
viii

14. Clackamas Heights model with fault . . . . 50

15. Clackamas Heights model faulted and adjusted 51

16. Oak Grove gravity model from, Jones (1977) . 59

17. Brothers Fault zone as related to the

Portland Basin, from Lawrence (1976) . . . 62

18. Tectonic map of the greater Portland area

from Tolan and others (1989) . . . . . . . 64

19. Portland area structural interpretation . . 66 


\section{INTRODUCTION}

\section{PURPOSE OF STUDY}

There is growing concern over the possibility of earthquakes in the Pacific Northwest. In an effort to assess earthquake hazards caused by movement along near surface faults in the Portland area, work is being done by the U.S. Geological Survey and the oregon Department of Geology and Mineral Industries to locate and map these faults. Visible evidence of faults is poor to nonexistent, therefore other methods must be used to locate these faults. Gravity surveys and the compilation of available Portland area gravity data may provide information to assist in addressing these problems. Once faults are located, they can be mapped and examined to determine when the most recent movement occurred. The timing of fault motion is also necessary to reconstruct the structural history of the Portland Basin.

Gravity modeling will be used to test the hypothesis that the gravity anomaly at oak Grove, Oregon is a basalt high rather than an intrusive related to the Boring Lavas. The model will be continued across the basin to the northeast to examine other structures. A separate gravity model will be used to locate the Portland Hills Fault near 
Clackamas Heights, oregon.

Gravity maps will be constructed to include all gravity data available at a larger scale to show more detail of the study area than the present state gravity map.

\section{LOCATION AND EXTENT OF STUDY}

The study area encompasses the Portland Basin located at the northern end of the willamette valley in northwest oregon. The area covered by the gravity maps extends from 122 to 123 degrees 30 minutes west longitude and between 45 to 46 degrees north latitude (Figure 1). Two modeled gravity lines are identified as the oak Grove line, named after a previous model by Jones (1977), and the Clackamas Heights line, located northeast of Clackamas Heights (Figure 2).

The Oak Grove Line begins near Seal Rock, on the oregon coast, and extends northeast into the Washington Cascades with detailed modeling extending from Petes Mountain to the Columbia River. The complete line contains 253 gravity stations, 208 of which are part of the detailed portion crossing the Portland Basin. These stations were taken from previous surveys of the area. The Oak Grove line was remodeled due to a more complete understanding of the subsurface configuration.

The regional model generated for the oak Grove Iine was modified and used for the clackamas Heights line due to the 


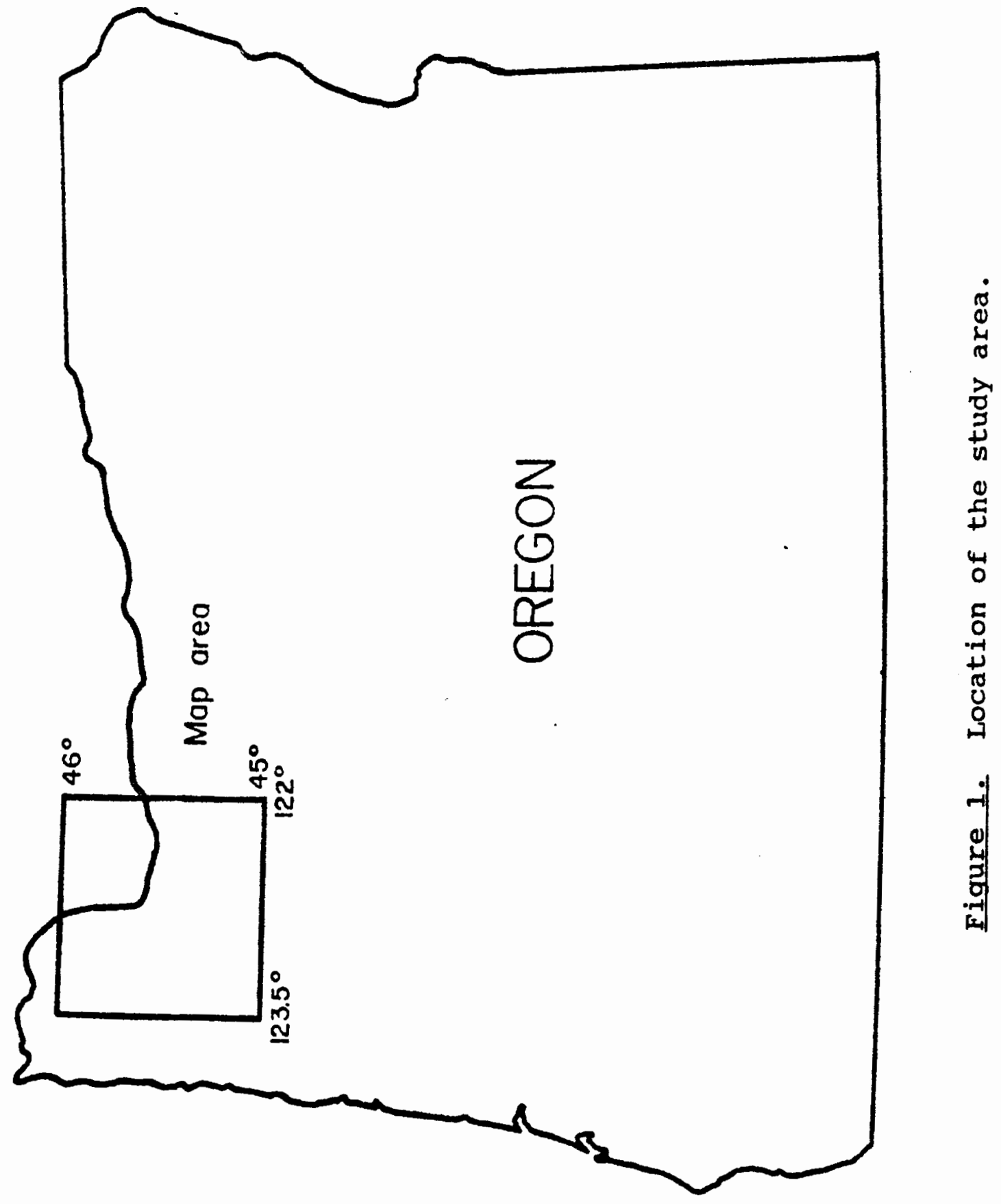




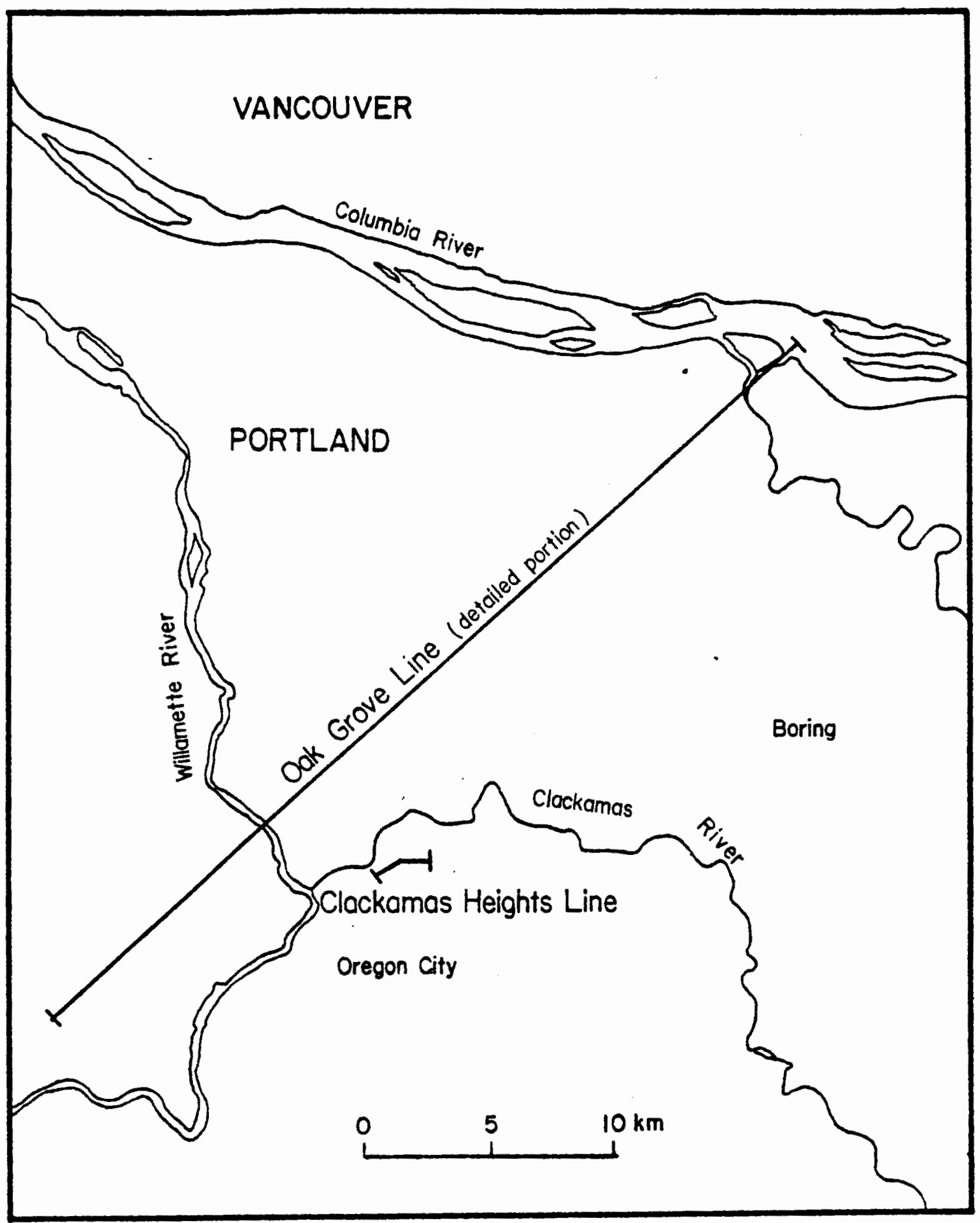

Figure 2, Location of gravity lines. 
close proximity of the small line. The detailed section of the Clackamas Heights line contains 51 gravity stations surveyed and measured during the spring of 1990. The placement and station spacing along the clackamas Heights line was based on the following criteria: 1) a preliminary map by Madin (1990) which located the possible fault blocks from drill hole data, 2) the existence of a road across the possible fault allowing ease of access to maximize efficiency and accuracy of the survey, 3) the expected depth to the fault, and 4) the low density of dwellings allowing further investigation of the fault if located.

\section{PREVIOUS WORK}

The greater Portland area has been mapped at a reconnaissance level by Treasher (1942) and Trimble (1963) with detailed mapping of the Lake oswego quadrangle by Beeson and others (1989). Diller (1915) was the first to recognize the possible existence of the Portland Hills Fault due to the strong northwest lineation along the east edge of the Portland Hills. Balsillie and Benson (1971) also suggested a fault along the Portland Hills based on structural, geomorphic and seismic evidence. Benson and Donovan (1974) constructed a preliminary tectonic map of the Portland Basin. Tolan and Reidel (1989) compiled a structure map of the Columbia River flood-basalt province which encompasses the Portland Basin. Beeson and others 
(1976) using three gravity lines as well as detailed mapping using geochemistry concluded that the west margin of the Portland Basin is possibly bounded by a right lateral strike-slip fault. Anderson (1978) concluded that subhorizontal slickensides in the clackamas river drainage could possibly be related to the Portland Hills fault trend. Schmela (1971) used gravity surveys to study the lower Clackamas River lineation. Six gravity traverses revealed a $2.18 \mathrm{mgal}$ (milligal $=.001 \mathrm{~cm} / \mathrm{sec}^{2}$ ) per 321 meters decrease to the east crossing the Iineation, however, this data was not modeled. Jones (1977) modeled a gravity line across the Portland Basin and concluded that the west side of the basin near Oak Grove was vertically offset approximately 300 meters. Davis (1987) defined the eastern margin of the Portland Basin using two separate gravity lines and concluded that the Lackamas Creek and Sandy River faults were linear zones with normal and/or graben like failure which parallel the Portland Hills features. Perttu (1980) measured gravity throughout the Portland Basin and modeled four east-west lines which showed the extension of a gravity high projecting north and northeast into the Portland Basin from the Milwaukie-Gladstone area. Berg and Thiruvathukal (1967) prepared Complete Bouguer anomaly and free-air anomaly maps of oregon at 1:64,000 scale.

Guineberteau and others (1987) used gravity surveys to examine the Mortagne pluton which probably infilled a pull- 
apart structure along the South Armorican Shear Zone in France. 


\section{GEOLOGY}

\section{STRATIGRAPHY}

\section{Introduction}

The generalized geology of the Portland Basin is shown in Figure 3. The oldest unit exposed in the area is the Waverly Heights basalt found along the Willamette River at Waverly Heights in Milwaukie, oregon. This is overlain by the Columbia River Basalt Group which crop out in the Tualatin Mountains, along the clackamas and columbia Rivers, and around and within the Tualatin Basin.

The stratigraphy below the Columbia River Basalt Group in the Portland Basin is poorly defined due to the lack of deep well data. The primary information for the stratigraphy below the basalt comes from two deep wells west of the Portland Basin, the Richfield oil Barber well and the Texaco Inc. Cooper Mountain Well, which penetrate to a maximum depth of 2825 meters (see Figure 3). These wells intercepted marine sediments at approximately 335 meters and produced frothy salt water, one at 29 barrels per hour (Newton, 1969). These two wells supply important information required in gravity modeling, however they do not furnish subsurface information south of Portland near the gravity model. The understanding of the geology above 


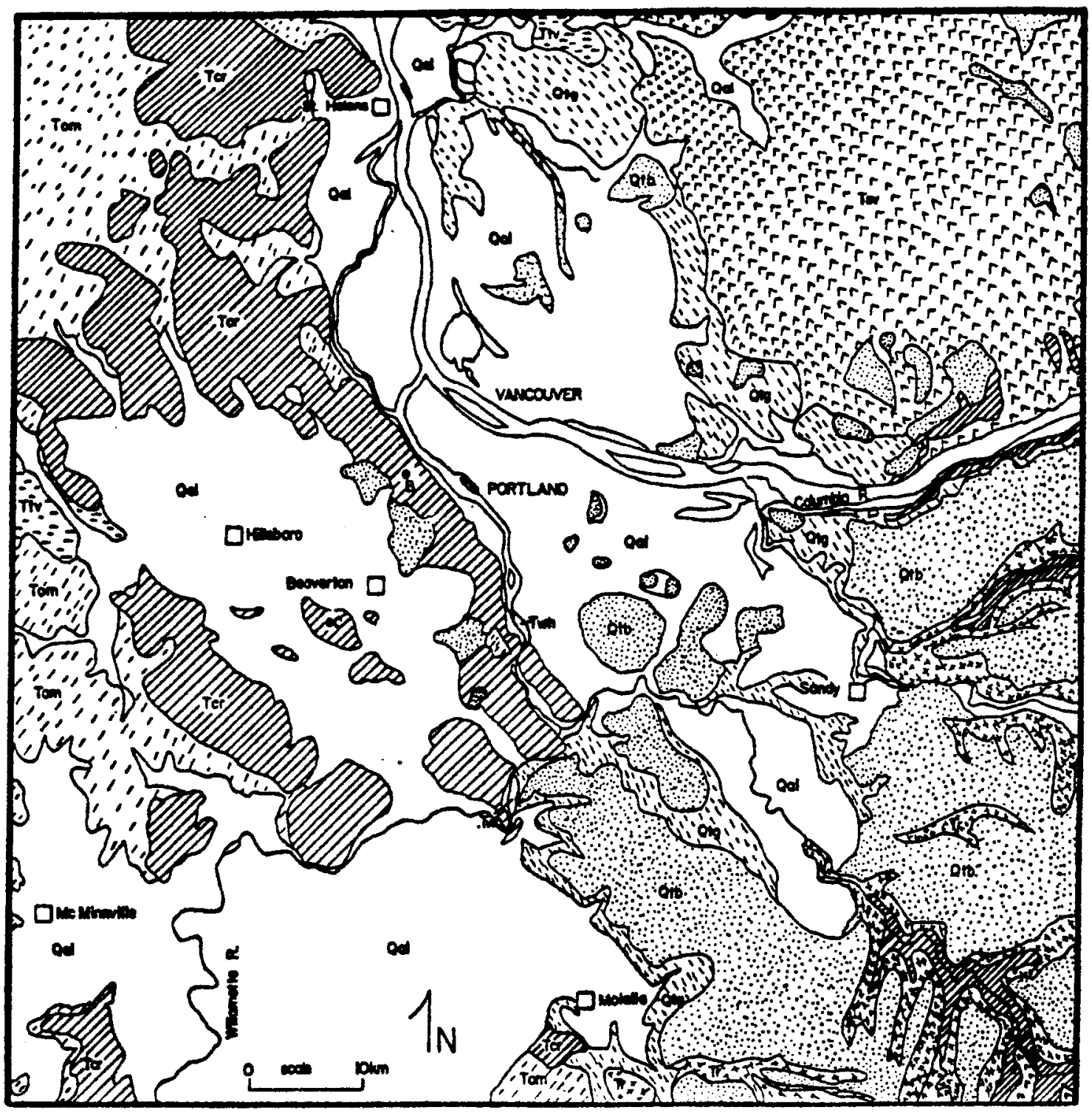

Twh Waverly Heights basalt, Tom Marine sediments, Tsv Skamania Volcanics, Ter Columbia River Basalt Group, Tr Rhododendron Formation, Qtg Troutdale Formation, Qtb Boring Lavas, Qal Alluvium. c Cooper Mountain well, B Barber well.

Figure 4. Geologic map of the Portland area from Tolan (1989). 
the Columbia River Basalt Group is growing due to close examination of new water wells and observation of preconstruction drilling programs.

\section{Siletz River Volcanic Series}

The Siletz River Volcanic series, which crops out in the central coast Range and along the western edge of the Willamette Valley, consists of marine basalt flows, pillow lavas, flow breccia, and pyroclastics with minor amounts of water-laid tuff (Beaulieu, 1971). These volcanics are presumed to be the core of the Coast Range. The estimated thickness of the Siletz River Volcanic Series is from 9 to $16 \mathrm{~km}$, which Phillips (1988) suggests is indicative of seamount volcanism of intra-plate or spreading ridge type. Inferred eruptive settings include island arc, mid-oceanic ridge basalt, oceanic-intra-plate (seamount), and ridgeisland (Icelandic) (Phillips, 1988). The Siletz River Volcanic Series was intercepted at -2800 meters in a well drilled in 1945-1946 by Texaco, Inc. known as the cooper Mt. 1 well located in the Tualatin Basin (Newton, 1969). This term is sometimes given to rocks of similar age and lithology exposed to the north that are otherwise included in the lower Tillamook Volcanic series (Beaulieu, 1971).

\section{Tillamook Volcanics}

Warren and others (1945), described a thick accumulation of Eocene volcanics in northwestern oregon and 
assigned the term Tillamook Volcanics (Beaulieu, 1971). Since then, the upper section of the unit has been referred to as Goble Volcanics and Nestucca Formation. The Tillamook Volcanics have been dated at about 46-41 $\mathrm{Ma}$ and are chemically classified as fore arc volcanics (Phillips, 1988). It has been suggested that the Goble Volcanics be separated from the fore arc volcanics because of their arc related affinities (Phillips, 1988). The lower part of the unit is often referred to as part of the siletz River Volcanics which is a term used predominately in exposures to the south. This section is approximately 1525 meters thick west of the Portland Basin. Newton (1969) considers the Yamhill-Tyee to be Tillamook equivalents and shows them interfingering between the Portland Basin and the Tualatin Basin (Figure 4). The upper Tillamook Volcanics or Goble Volcanics and Cowlitz-Nestucca Formation are also shown as interfingering in the Portland area (Newton, 1969).

\section{Skamania Volcanic Series}

The Skamania Volcanic Series consists of basalt flows, basaltic andesite flows and pyroclastic rocks exposed along the south shore of Lady Island, the north shore of the Columbia River, and throughout the Cascade Mountains in Washington (Trimble, 1963). Mundorff correlated a group of low hills near Camas, Washington with the Skamania Andesite Series of Felts (Hogenson and Foxworthy 1965). The position 


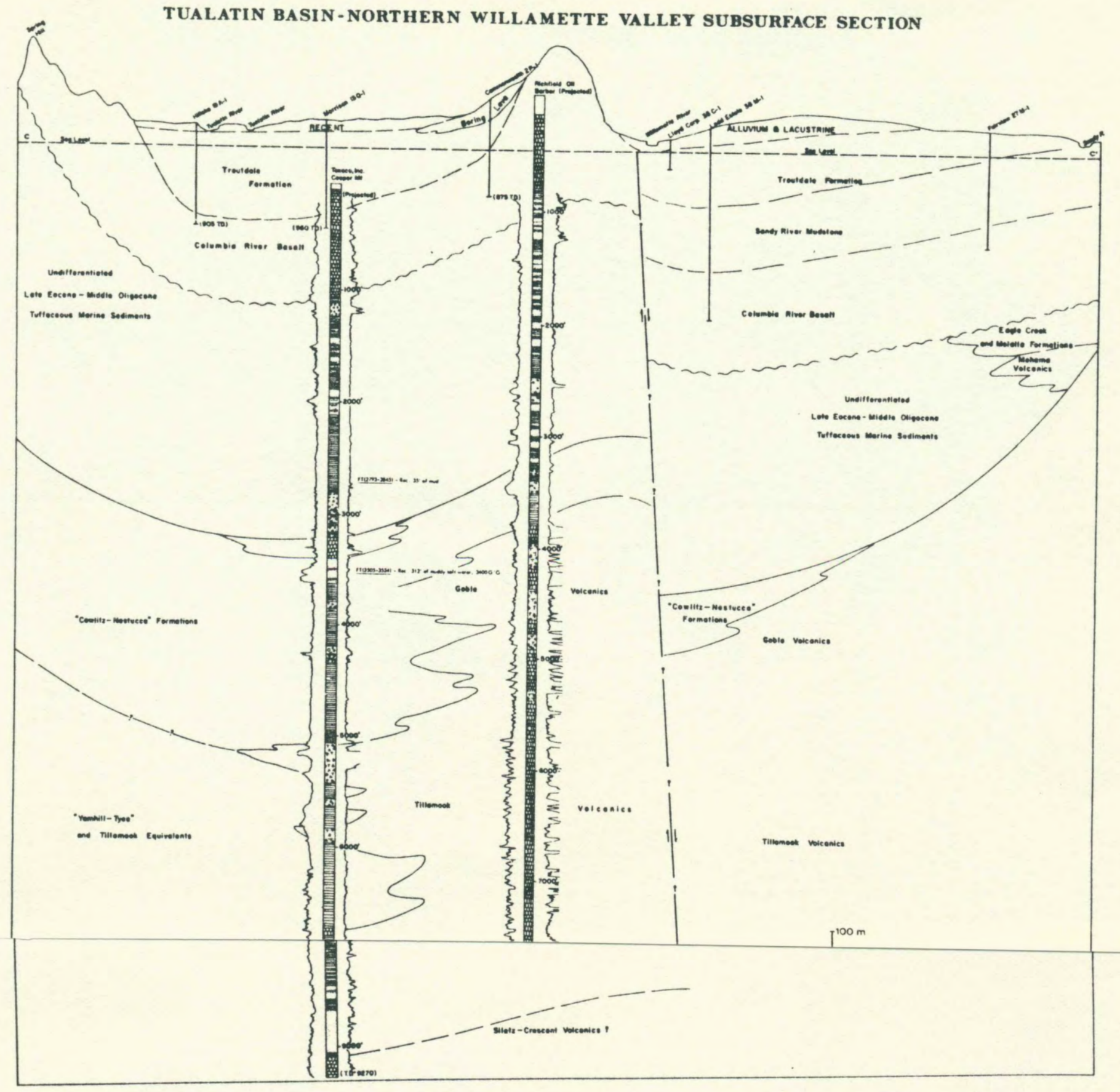

Figure 4. Portland area subsurface cross-section from Newton (1969) 
and extent of these volcanics suggest deformation prior to the extrusion of the Columbia River basalt, preventing the basalt flows from covering them (Hogenson and Foxworthy 1965). Trimble (1963) also identified a small exposure south of oregon city as being Skamania volcanics, now known to be Waverly Heights basalt (Marvin H. Beeson, personal communication, 1989). Volcanic rocks were intercepted in the Richfield Barber No. 1 well at about 300 meters below sea level. The volcanics were described as Skamania volcanics based on lithology without the aid of chemical analysis, but there actual identity is unknown. The Skamania volcanics were grouped together by Newton (1969) as undifferentiated late Eocene to middle Miocene tuffaceous marine sediments (see Figure 4 ).

\section{Waverly Heights Basalt}

Beeson and others (1989) described the oldest rocks exposed in the Portland area. The Basalt of Waverly Heights consists of subaerial basaltic lava flows and associated sediments, dated by $\mathrm{K}-\mathrm{Ar}$ at approximately $40 \mathrm{Ma}$. The Waverly Heights basalt crops out along the willamette River at Waverly Heights near Milwaukie, Oregon (see Figure 3). The sediments however, are mostly found in boreholes and data suggest a marine depositional environment. The surface of the Waverly Heights basalt is weathered to a depth greater than 9 meters, representing the 25 Ma which elapsed 
between units. The waverly Heights basalt is possibly part of an accreted oceanic plate of which the waverly and Tillamook Highlands were a part. Beeson and others (1989) note that the Waverly Heights basalt is chemically similar to the Tillamook volcanics. The actual stratigraphic relationship of the Waverly and the late Eocene sediments is unknown. However, the sediments probably surround the Waverly basaltic high and interfinger with arc sediments to the east.

\section{Columbia River Basalt Group}

The Columbia River Basalt Group overlies both the Skamania volcanics and the Waverly Heights basalt. The Miocene Columbia River basalt flows were erupted from 17 to 6 Ma from fissures in northeastern oregon, eastern Washington, and western Idaho (Beeson and Tolan, 1988). The basalt flowed west, filling topographic lows and thinning around topographic highs, preserving a record of the preexisting topography. The willamette Valley having low relief and being close to sea level and underlain by marine or estuarine sediments was covered by some of the first Columbia River basalt flows (Beeson and others, 1989). These flows created an aerially extensive and relatively flat plane which Beeson and Tolan (1988) use as a reference datum to determine post emplacement and coeval deformation. The Columbia River basalt has recorded nearly continous 
tectonic activity through the Tertiary (Beeson and others, 1974). The basalt flows crop out primarily on the basin edges and are covered by 300 to 400 meters of Pliocene to Pleistocene fluvial sediments in the deepest parts of the basin.

\section{Sandy River Mudstone}

The Sandy River Mudstone consists of lake beds or overbank deposits composed of mudstone, siltstone, claystone and very fine sand. These deposits are dated as early Pliocene based on flora found along the upper contact (Trimble, 1963). The mudstone possibly represents overbank deposits in the Portland Basin prior to the development of channeled drainage across the basin. The mudstone is thought to underlie most of the Portland Basin with thicknesses described from wells ranging from 30 to 220 meters. It is not found along the Union Pacific railroad track west of Corbett (Trimble, 1963), possibly due to faulting. The Sandy River Mudstone is best exposed along the sandy River for which it was named by Trimble (1963).

\section{Troutdale Formation}

The Columbia River basalt and Sandy River Mudstone are overlain by the Miocene/Pliocene Troutdale Formation. The Troutdale Formation originally defined as one unit by Hodge (1938) consists of two distinctive members (Tolan and Beeson, 1984). The lower member represents channel 
deposition by an ancestral columbia River and is confined to an area near the present channel. This member is characterized by pebble-cobble conglomerates consisting predominantly of Columbia River basalt with foreign clasts of quartzite and micaceous arkosic sandstone beds (Tolan and Beeson, 1984).

The upper member is composed of locally derived pebbly to cobbly vitric sandstone with basaltic conglomerate interbeds consisting of basalt clasts from Boring and Cascade lavas (Tolan and Beeson, 1984). The vitric sandstones consist of angular glass, suggesting a local source of lava flowing into the columbia River along its course through the Cascade Mountains (Trimble, 1963). The influx of large amounts of volcanics into the river probably caused the river to aggrade and spread out across the Portland Basin to distribute the increased sediment load. The Troutdale sands and gravel reached thicknesses of 600 meters in the Portland Basin.

\section{Boring Lavas}

The Boring Lavas are Plio-Pleistocene volcanics erupted from 90 vents throughout the Portland and Vancouver area. They generally overlie the Troutdale Formation (Allen, 1975), and consist primarily of high-alumina basalt with minor amounts of pyroclastics which formed conical hills and broad lava plains on the dissected Troutdale Formation 
(Trimble, 1963). Treasher (1942), gave the name "Boring Lavas" to these volcanics due to the great concentration of vents located west of the town of Boring where 20 volcanic centers are located within an area of 36 square miles (Allen, 1975). Buttes within the Portland Basin such as Mount Tabor may be caused by geothermal systems generated by Boring Lavas vents creating convective cells which precipitated a cement making them more resistant to erosion (Beeson and Nelson, 1978).

\section{Pleistocene To Recent Sediments}

Deposits of boulders, gravel, and sands throughout the Portland Basin represent catastrophic flooding of the area due to the repeated failure of glacial ice dams that impounded glacial Lake Missoula (Waitt, 1985). The most recent of these floods occurred between 15,500 to 13,000 years B.P. eroding an estimated 60 meters of Troutdale Formation leaving the more resistant buttes and depositing sediments due to hydraulic damming (waitt, 1985).

\section{STRUCTURE AND TECTONICS}

The Paleogene stratigraphy of the coast Range consists of possibly accreted tholeiitic basalt of probable seamount origin assigned to the siletz River Volcanics as well as post-accretion basaltic rocks of alkalic composition (Heller and others, 1987). The pillow basalts of the siletz 
formation are low potassium tholeites similar to basalt formed at oceanic ridges (Snavely and others, 1968). The post-accretion volcanics comprised of basalt, diabase, and gabbro are interbedded with or injected into the sediments of the coastal basins (Heller, 1987). The Tillamook Volcanics are thought to be the post-accretion volcanics erupted as subaerial flows in a fore arc basin setting which overlie a base of pillow basalt (Heller, 1987). The Coast Range basalts are thought to have been erupted from about 62 to $48 \mathrm{Ma}$ and accreted by 50 to $48 \mathrm{Ma}$ to North America (Phillips and others, 1988).

At approximately $60 \mathrm{Ma}$ and culminating at approximately $35 \mathrm{Ma}$, the calc-alkaline volcanism shifted from the challis arc of central Idaho and surrounding area to the Cascade arc of western oregon and Washington (Phillips and others., 1988). The cause of the trench jump and subsequently the arc jump is not known but one possible cause is the jamming of the subduction zone by seamounts (Perttu, 1976). However, Heller (1987) notes that the accretion took place about $50 \mathrm{Ma}$, but the Challis arc had already migrated west between 60 and 55 Ma therefore, the relationship between these two events is unclear. There is the possibility that the challis arc is not a remnant arc rather a result of rifting of that area during this time. At 60 to 55 Ma this extension would have been a relatively separate event. This would suggest that the trench never jumped. This would 
allow the siletz formation and Tillamook Volcanics to have formed in place at $50 \mathrm{Ma}$ or accreted rather than clogging the subduction trench.

A fore arc type basin was formed during middle to late Eocene receiving turbidites of the Flournoy and Tyee Formations (Drake, 1982). The Yamhill-Tyee formation was deposited in the Portland area during this same time but, possibly due to less rapid sedimentation or uplift, the section is much thinner in Portland area (Perttu, 1980).

One aspect of the late Eocene is the tectonic rotation of terrane throughout the region as indicated by paleomagnetism (Heller, 1987). The Siletz and the Tyee formations are rotated 50 to 70 degrees clockwise from the Eocene magnetic field (Simpson and Cox, 1977). Three models have been proposed to explain this rotation. The first, model explains the rotation by pivoting the oceanic rigid fragments during collision with North America (Simpson and Cox, 1977). In the second model, rotation results from later extensional deformation in the cordillera that began after the collision was complete (Simpson and Cox, 1977). In the third model Beck (1980), attributes extension to a right-lateral shear couple driven by oblique subduction of oceanic plates to the west (Heller, 1987).

This regional shear is possibly represented along the boundary between the Cascade Range and the willamette Valley where a northwest-trending wrench fault zone is 
characterized by right-lateral strike-slip and dip-slip faults. Near Portland the shear has deformed the Columbia River basalt into a faulted northwest-trending asymmetrical anticline (Beeson and others, 1985). Tectonic activity occurred during this time as indicated by a decrease in thickness of Columbia River basalt from approximately 600 meters in the Clackamas River area (Anderson, 1978) to approximately 150 meters in the Molalla River area and willamette Valley (Beeson and others, 1985).

The Willamette Valley was probably not a strong northsouth topographic feature at this time as indicated by the lack of the early basalt flows in the center of the present valley (Beeson and others, 1985). The distribution of Ginkgo and Sand Hollow Members indicates the Portland Basin existed during the middle Miocene time (Beeson and others, 1985). The Portland Hills possibly formed as a result of right-lateral movement along the Portland Hills fault (Beeson and others, 1976). Beeson and others (1985), conclude that the Portland Basin is a pull-apart basin genetically related to the Portland Hills-Clackamas River structural zone.

Deformation of the Portland Basin probably continued through the deposition of the Troutdale Formation shown by the gentle dip toward the west (Swanson, 1986). Other evidence of recent deformation presented by Swanson (1986) is the 150 meter downward offset of the Troutdale Formation 
from Prune Hill, Washington to the Elue Lake area on the Oregon side of the Columbia River. 
ANALYTICAL METHODS

DATA

\section{Introduction}

Variations of gravity on the earth's surface are dependant on five factors; latitude, elevation, topography of surrounding area, earth tides, and lateral density variations (Telford, 1986). Abrupt gravity variations, or anomalies, are usually related to structures such as faults which juxtapose formations of different densities. The shape of the anomalies depend on three factors; the magnitude of the density contrast which controls the amplitude of the anomalies, depth to the offset controlling the wavelength, and the geometry of the feature which controls the shape of the anomalies (Telford, 1986). The other factors such as latitude, elevation, topography, and tides can be corrected for, leaving the anomaly caused by subsurface geologic structures.

\section{Theodolite survey}

The location of the gravity stations must be determined in order to apply several correction factors. Each gravity station must be located within 12 meters north-south to assure an accuracy of .01 mgals. The gravitational change 
with latitude is caused by the earths rotation and equatorial bulge, resulting in increased gravity with increased latitude (Telford, 1986). Gravity varies as the distance from the center of the earth changes due to topography. The station elevations must be measured to 0.05 meters to assure gravity measurements accurate to .01 mgals.

Vertical and horizontal distances were determined using a wild T2 Theodolite and Pentax electronic distance measure and utilizing standard surveying techniques. Vertical control for the clackamas Heights line was obtained from intersection elevations at Highland street and Forsythe Road, elevation 95.1 meters, and Beaton Road and Forsythe Road, elevation 98.45 meters. These elevations were taken from the 1984 photorevised Gladstone, oregon 15' quadrangle map.

\section{Gravity survey}

Gravity measurements were obtained using a Texas Instruments worden Gravity Meter, Master Model III, \#668 with a sensitivity of $.1091 \mathrm{mgals} / \mathrm{scale}$ division. The gravimeter is equipped with an internal heater to prevent temperature fluctuations which affect the accuracy of the survey. Gravimeter temperature was recorded before the three measurements were taken at each station. An established base station in the lobby of the Geology Department, Portland State University, with an absolute 
gravity value of $980641.35 \mathrm{mgals}$, was occupied at the beginning and end of each field day. This value was used to determine the absolute values of the field stations. One field station, (station B) was reoccupied every hour each day to determine daily instrument drift.

The Clackamas Heights line was surveyed with the specific purpose of locating a segment of the Portland Hills fault for further study, possibly trenching, to determine latest movement. For this reason, stations were located at 30 meter spacing across the expected position of the fault. Control stations were spaced 60 meters or more near the ends of the line where detail was not needed.

\section{Data reduction}

The three readings taken at each station were first averaged, then multiplied by the small dial constant for the appropriate temperature. This converts the reading to milligals. Before this number can be related to the absolute gravity, a time dependent drift correction must be applied. There are two causes of drift. Mechanical creep in the springs causes a unidirectional change in the gravimeter and earth tides which cause cyclical changes in measurements (Telford, 1976). These changes caused by earth tides are significant but change slowly, over 12 and 24 hour periods, therefore both drift corrections can be accounted for in the instrument drift correction (Telford, 1976). 
Once the drift of the instrument is corrected, the field readings are converted to absolute gravity by relating the readings taken at Portland state base station to the field base values.

Terrain corrections are used to correct for surface irregularities in the vicinity of the station. Hills that rise above the station reduce the reading because of upward attraction while valleys reduce the reading due to lack of downward attraction. Since both reduce the reading, the terrain correction is always added to the station reading (Telford, 1976). The graphical method created by Hammer and described by Dobrin (1960) was used to calculate the terrain correction for $1 / 3$ of the stations. Due to the small variation, from .15 to .34 mgals, values were extrapolated between stations.

Using the corrected gravity values at each station along with the terrain corrections, free-air and Bouguer gravity values were calculated (see Appendix). Many different constants are available for these calculations which have changed with the ability to measure gravity more accurately. For this reasons, the constants and equations used are listed in the Appendix.

\section{Data compilation}

Gravity data covering the greater Portland area have been collected over many years. The data include stations 
from the U.S.G.S gravity tape as well as data collected by M.S. students at Portland state University including Schmela (1971), Jones (1977), Perttu (1981), and Davis (1987). Data from Beeson and others (1975) fault identification report were also included. The data were entered in a microcomputer data base, which includes over 1600 data points in the area from 45 to 46 degrees north latitude, and from 122 to 123.3 degrees west longitude. The observed gravities and terrain corrections from the original surveys were used to recalculate complete Bouguer gravity and freeair values to prevent irregularities caused by the use of different constants and different degrees of precision. The data collected for the clackamas Heights line were also added to these data. 
GRAVITY MAPS

\section{PRODUCTION}

Three gravity maps were generated using a personal computer and Golden Software. The data were first converted from longitude and latitude to a coordinate system to allow the use of the software. Secondly, coordinate data were used to create a fine grid using the Grid program. once the grid was generated a topographic map of the gravity was developed using the Topo program. These maps were then printed at the desired scale. Finally, the map was edited and drafted for final copy by hand.

\section{Complete Bouguer Gravity Map}

The area covered by the complete Bouguer Gravity Anomaly Map as well as the Residual complete Bouguer Gravity Map and the Free-Air Gravity Anomaly Map is shown by Figure 1. The gravity maps are reduced from 1:250,000 scale and cover all but the western one-half degree of the Vancouver 1 x 2 Degree Series map.

The Bouguer gravity values have been adjusted for latitude, elevation, and land mass above sea level. Therefore, these values reflect lateral density variations and irregularities associated with geologic structures. The 
map is contoured at five mgal intervals (Figure 5).

\section{Residual Gravity Map}

A gravity gradient of one mgal per kilometer from west to east, caused by the thickening crust, is apparent on the Complete Bouguer Gravity Anomaly Map of Oregon by Berg and others (1967) shown by Figure 6. This gradient masks local shallow features with north-south contours. The local features were accentuated by adding one mgal per kilometer from west to east with the results shown on Figure 7 . The absolute value of the contours are arbitrary and only reflect relative gravity differences.

\section{Free-air Gravity Map}

The Free-air Gravity Anomaly Map is shown in Figure 8 and is contoured at $10 \mathrm{mgal}$ intervals and shows the locations of all gravity stations used for contouring the gravity maps. Free-air gravity values represent the observed gravity value only corrected for changes in elevation. This correction does not account for the material between the gravity station and the datum plane to which the value is corrected. Without the correction for material above sea level the gravity reflects the topography as well as other gravitational changes. Free-air gravity maps show regional variations in iscistatic equilibrium. For example, an area recently covered by volcanics or uplifted, which has not reached isostatic equilibrium will 


\section{COMPLETE BOUGUER GRAVITY ANOMALY MAP of the GREATER PORTLAND AREA, OREGON}

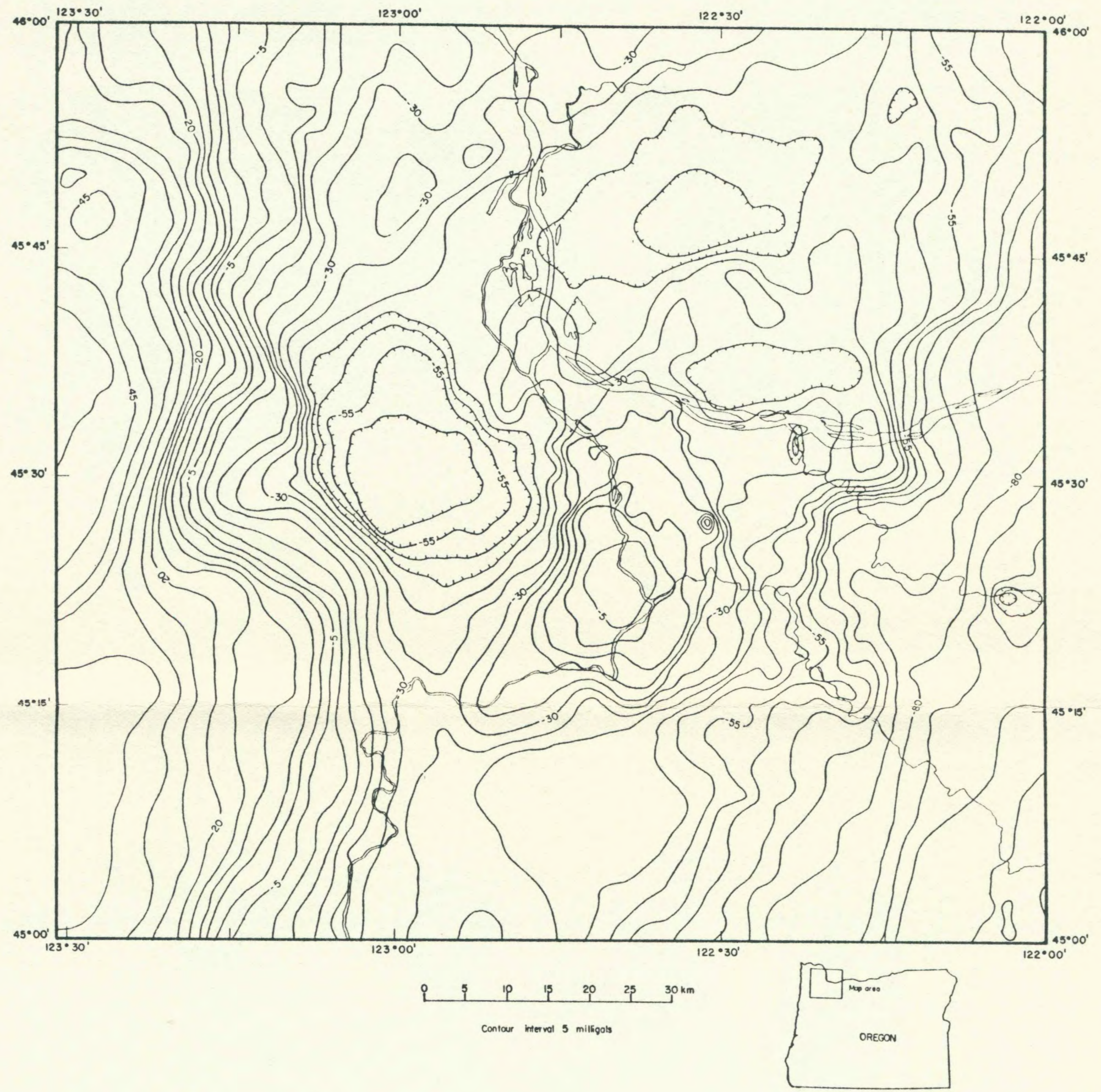

Figure 5. Complete Bouguer gravity anomaly map of the greater Portland area, oregon. 


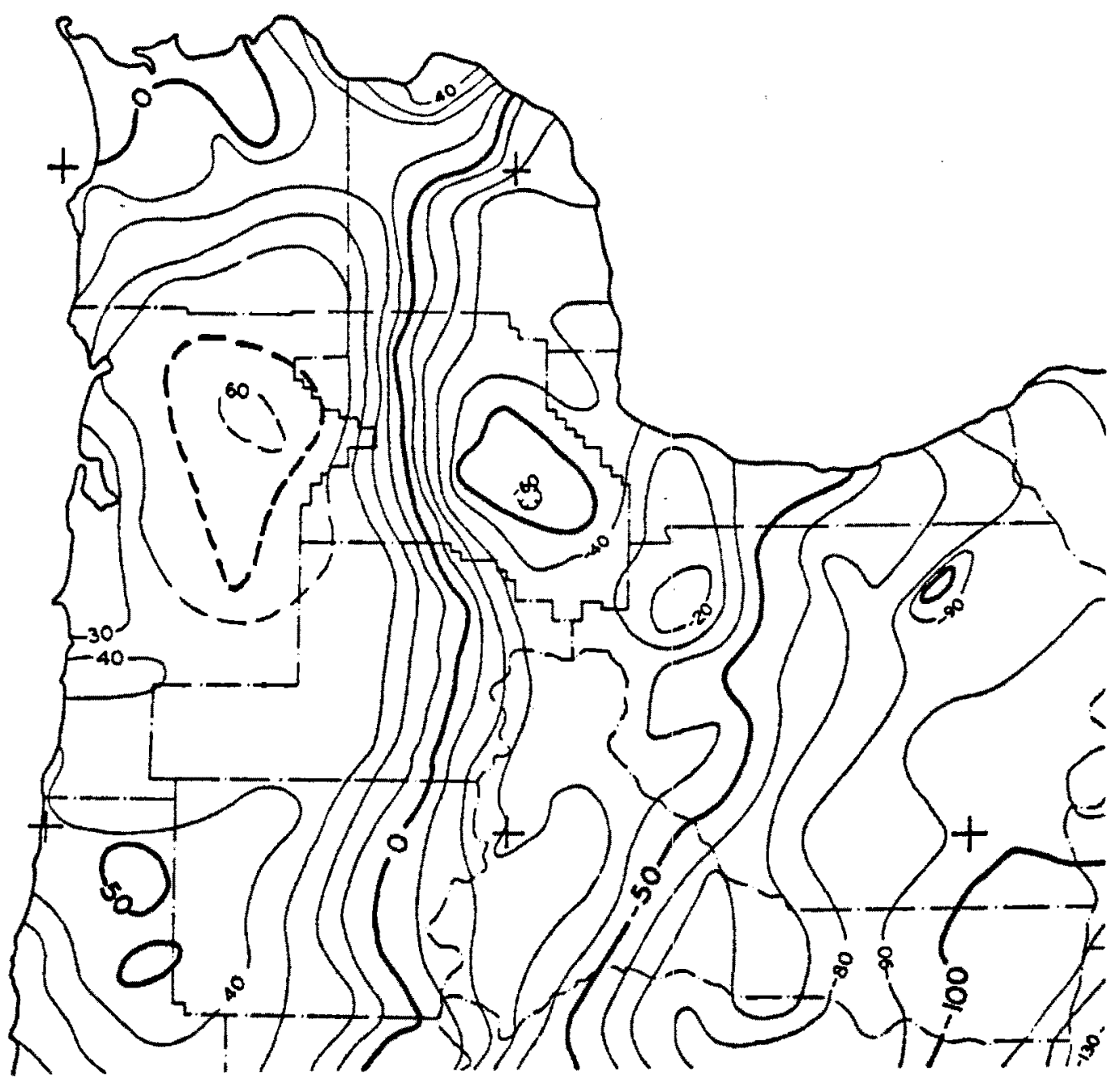

Contour interval 10 milligals, doshed where interred

The grovity anomaties reter to the intarnotional Govily Formula and o roch density of $2.67 \mathrm{~mm} / \mathrm{cc}$

Dota raductions boud on man seo level dotum

Grovily mop wos prepared of the Department of Oceonagrophy, Oregon Siale

Univer sity under the direlion of Josuph W. Bergi, tr, oseisted by John V.

Thinerothuket, 1967

Fiqure 6. Northwest corner of the state gravity map from Berg and Thiruvathukal (1967). 
RESIDUAL COMPLETE BOUGUER GRAVITY

ANOMALY MAP of the GREATER

PORTLAND AREA, OREGON

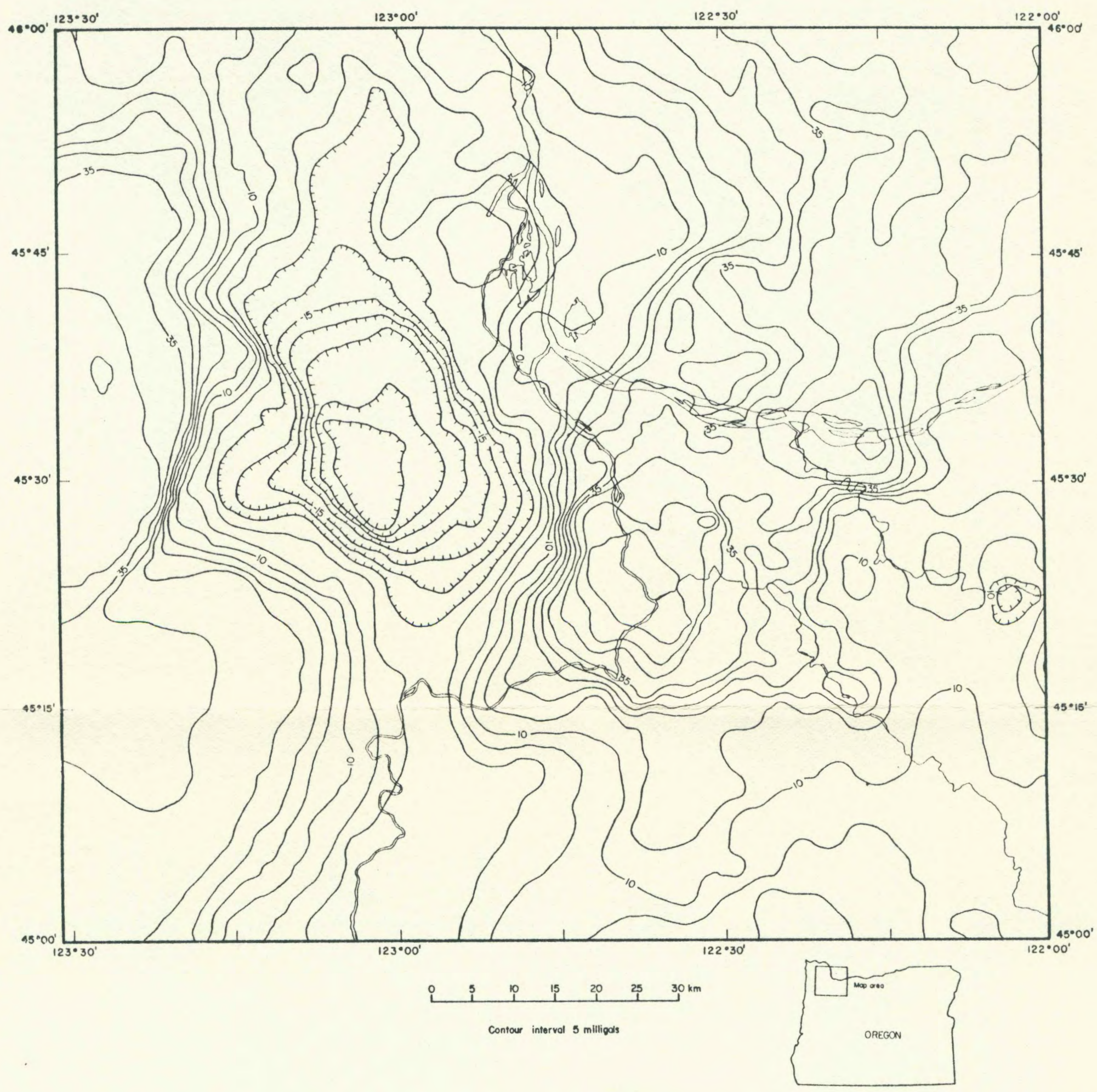

Figure 7. Residual complete Bouguer gravity anomaly map of the greater Portland area, Oregon. 


\section{FREE-AIR GRAVITY}

ANOMALY MAP of the GREATER

PORTLAND AREA, OREGON

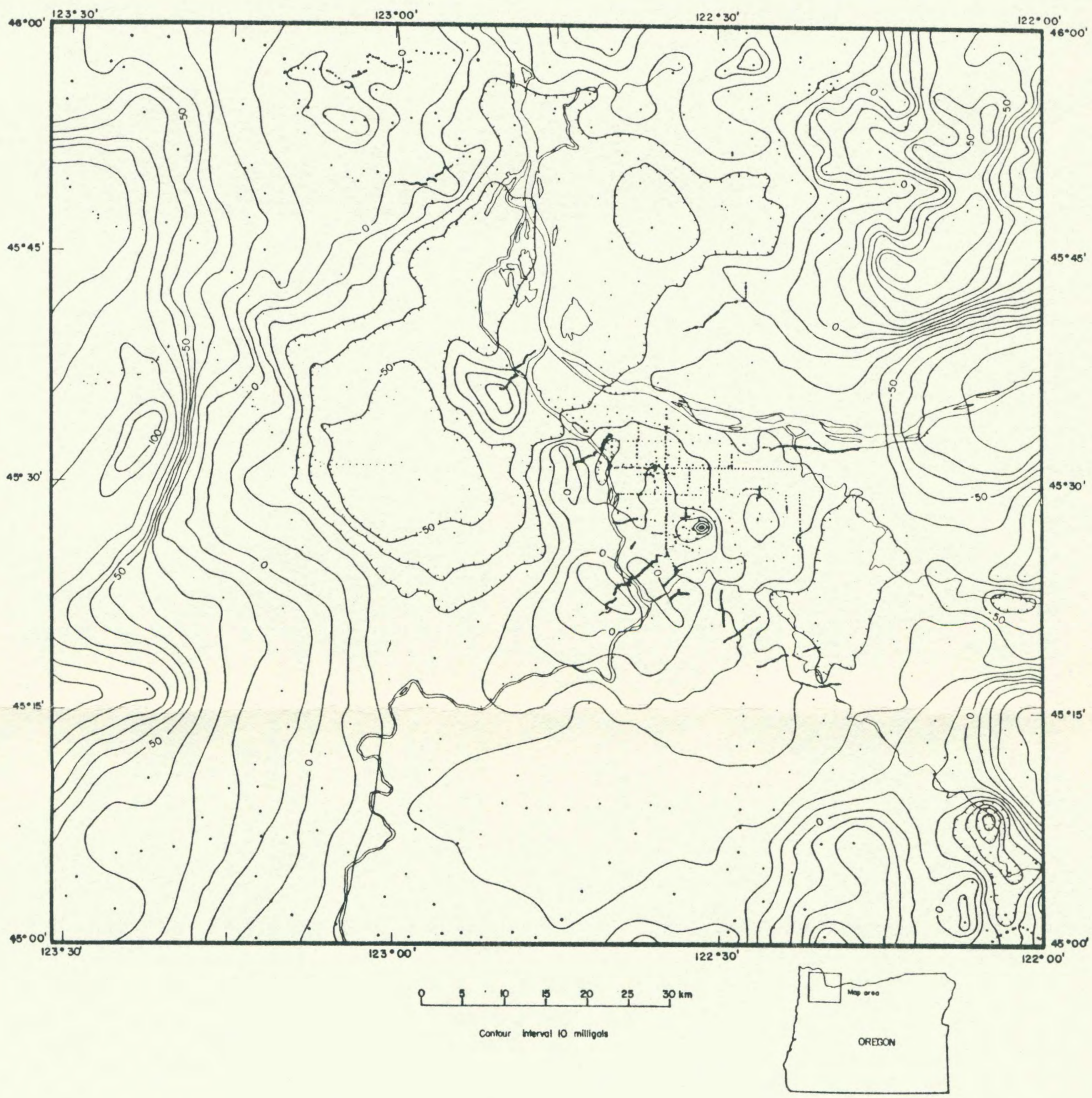

Figure 8. Free-air gravity anomaly map of the greater Portland area, Oregon with gravity station locations. 
be represented as a gravity high. Areas which have reached equilibrium show as zero gravity areas because the mantle has been displaced. 


\section{GRAVITY MODELING}

\section{INTRODUCTION}

Many geologic structures are approximately linear and can be evaluated using two-dimensional forms of analysis (Talwani, 1959). Geologic cross-sections are twodimensional representations of the subsurface geology. Gravity modeling involves the computation of the gravitational attraction of irregularly shaped twodimensional bodies such as the shapes represented on a geologic cross-section. Gravity modeling is concerned with the size and density of the two-dimensional bodies. Each two-dimensional body is referred to as a block which may include one or more formations of similar density. The block shapes may not reflect detailed inter-fingering of formations due to the fact that these subtle variations are obscured by the overall change in density as the facies change is traversed. Boundaries between blocks are represented as straight lines.

Anomalies are the direct result of density contrast caused by geologic structures and facies changes. The vertical density contrast between two different lithologies creates anomalies. This type of contrast is difficult to model because of the many possible configurations of 
formation thickness and density. Drill hole data must be used for this situation. Horizontal density contrast creates a shorter wavelength anomaly as the structure is traversed. The size and shape of the anomaly depends on depth to the contrast, the configuration of the blocks, and the magnitude of the density contrast. The wavelength of an anomaly on the surface is approximately equal to the depth to the density contrast generating the anomaly. Therefore, the greater the depth to the contrast, the longer the wavelength of the anomaly. Models are constructed to determine possible subsurface configurations.

The quantitative calculation of the gravitational effect of each block of the cross-section was performed using an algorithm developed by Talwani and others (1959). The algorithm is part of the modeling program developed by oregon State University and adapted for use on a personal computer.

Densities for each stratigraphic modeling unit must be determined before modeling can begin. Densities used by Finn (1988) were used to construct the first models and were later adjusted to densities used by Davis (1987). The density of the Sandy River Mudstone was determined later during modeling using a micropycnometer as described by winchell (1938). This density was calculated as $2.5 \mathrm{~g} / \mathrm{cm}^{3}$ and adjusted for porosity and saturation with water to at most $2.1 \mathrm{~g} / \mathrm{cm}^{3}$. The density of the Frenchman Springs member 
of the Columbia River Basalt Group was determined by Fassio (1990) using the same micropycnometer method as $2.87 \mathrm{~g} / \mathrm{cm}^{3}$ and is modeled as $2.8 \mathrm{~g} / \mathrm{cm}^{3}$ which is consistent with the density used by Davis (1987). Densities used for other Formations are listed in Table I.

\section{TABLE I}

MODELING UNITS

STRATIGRAPHIC UNIT

DENSITY $\mathrm{g} / \mathrm{cm}^{3}$

Alluvium - unconsolidated

1.7

material (Qal)

Troutdale Formation (Qtg) 2.5

Sandy River Mudstone (Tsr) 2.1

Waverly Heights basalt (Twh) 2.8

Pre Columbia River Basalt Group

sediments

2.4

Columbia River Basalt Group (TCr) 2.8

$\begin{array}{lll}\text { Skamania Volcanic Series (Tsv) } & 2.8\end{array}$

Tillamook Volcanic Series (Ttv) 2.8

$\begin{array}{ll}\text { Boring Lavas (Qtb) } & 2.87\end{array}$ 


\section{REGIONAL MODEL}

The construction of a regional model is the first step in gravity modeling. The regional model is intended to represent the actual geology. The primary reason for constructing the regional model is to place the local model in a realistic geologic framework to isolate it from regional gravity effects (Figure 9).

The model was extended $130 \mathrm{~km}$ beyond the end of the detailed line to avoid edge effects associated with using a two-dimensional model that can not be extended infinitely. Edge effects are caused by the calculation of the gravity at the end of the model where the contrast of the $50 \mathrm{~km}$ thick model ends leaving air against rock causing an abrupt decrease in calculated gravity. The placement of the short line within the regional model insulates the area of interest from these effects.

The gravity line was extended using gravity data taken from the U.S.G.S. gravity tape. The model starts at 44 degrees 30 minutes north latitude 124 degrees west longitude near Seal Rock on the Oregon coast, crosses the Portland Basin in a northeast direction and continues into the Washington Cascades. The gravity line crosses the Tualatin Mountains between Oak Grove and Gladstone and is situated perpendicular to the Portland Hills fault. The line continues across the basin to the northeastern edge and 


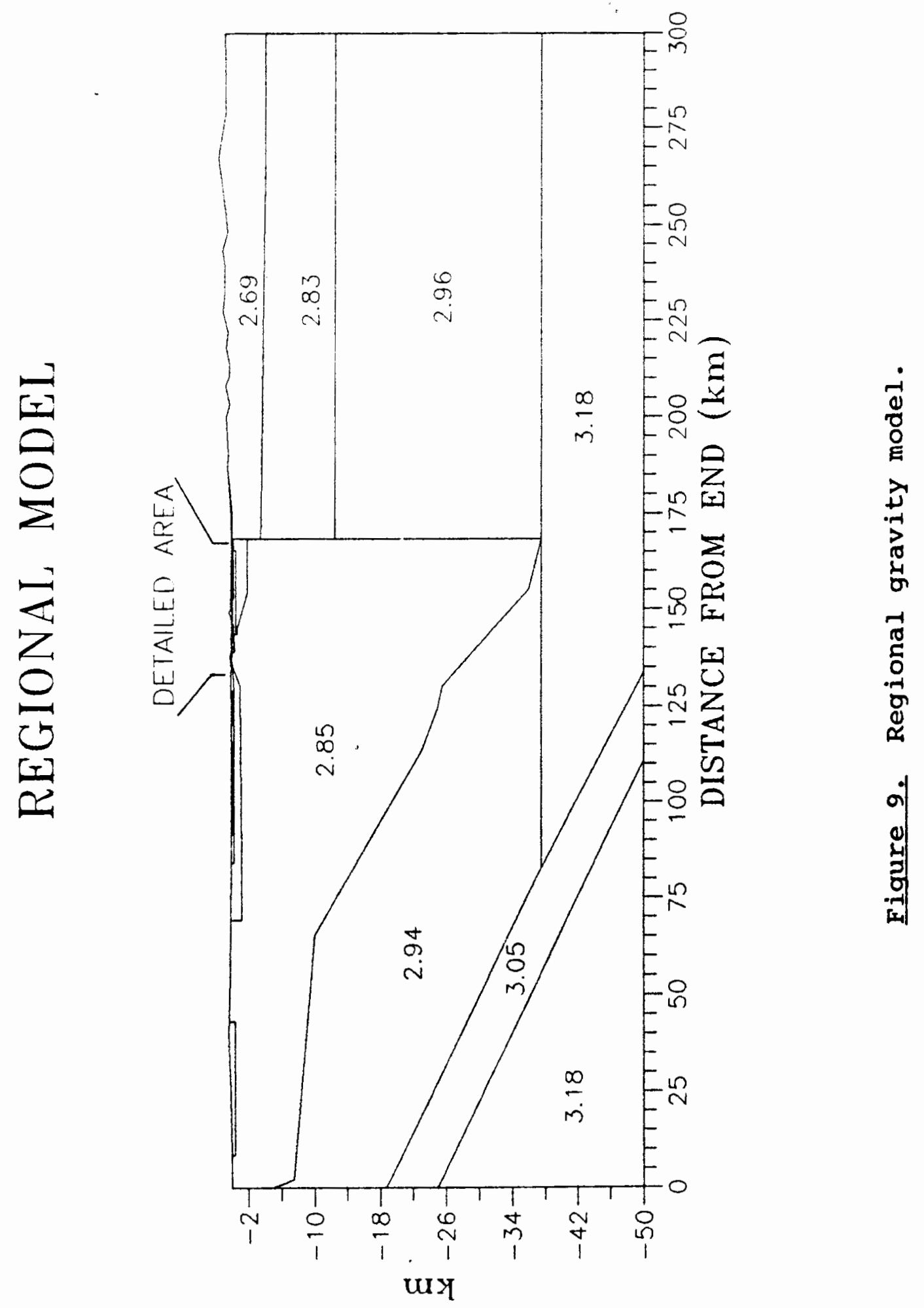


enters the Cascade Range of southern Washington where the data points are few. The starting model was constructed by combining several recent large scale geophysical studies that cross western oregon and southwestern Washington. The northern end of the large scale gravity line was constrained by using the Continent-Ocean Transect B3: Juan de Fuca spreading Ridge to Montana Thrust Belt published by the U.S. Geological survey as well as gravity and magnetics modeling done close to this same line by Finn (1988). The southern end of the large regional line was constrained using a conductivity cross-section constructed by Wannamaker and others (1988). These studies were used to help constrain the model to $50 \mathrm{~km}$ depth.

\section{LOCAL MODELS}

\section{Oak Grove Model}

The final free-air block model, topography, observed gravity and calculated gravity are shown in Figure 10. The detailed model of the Portland Basin was constructed to fit the known subsurface geologic data as accurately and as simply as possible.

The most prominent features of the model are related to the elevation. The Tualatin Mountains, Oatfield Heights, and Mt. Scott are pronounced gravity highs. These features are caused by the combination of dense basalt and elevation. The gravity values decrease from 21 mgals, progressing from 


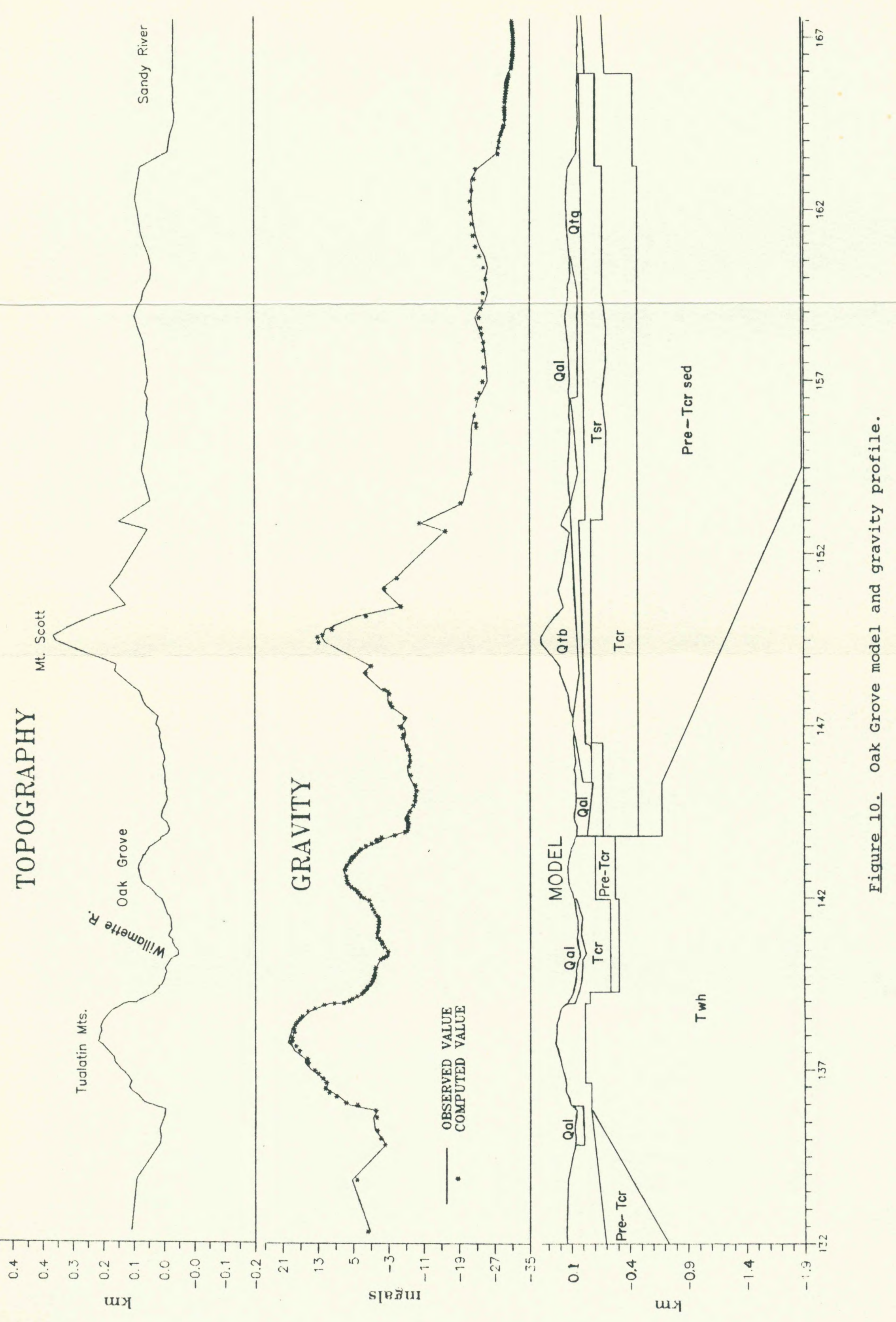


the Tualatin Mountains past oak Grove to 16 mgals northeast of Mt. Scott. The gravity decreases even though the elevation is the same or slightly greater. The decrease results from moving off the gravity high which is the pronounced feature near oak Grove shown on the gravity maps (see Figure 5). This high was originally modeled by Beeson and others (1975), Jones (1977), and Perttu (1980) as a high density intrusion related to Boring volcanism. Due to increased understanding and detailed mapping of the area by Beeson and others (1989), this high is now attributed to the Waverly Heights basalt. The Waverly Heights basalt crop out with limited exposure in the area of the gravity high. The actual extent of the feature must be estimated from the gravity anomaly due to the lack of subsurface geologic data to help place constraints on size.

The base of the Waverly Heights basalt is not included in the model because of the lack of density contrast between it and the older basalt. The Columbia River basalt directly overlies the Waverly Heights basalt but is known to be separated by a block of sediments in places. This is substantiated by the fact that a well drilled near Oak Grove passing through the Columbia River Basalt Group penetrated approximately 15 meters of sediment before drilling ceased (Hogenson, 1965). Sixty to 150 meters of sediment were required under oak Grove to fit the observed gravity. The east side of the high is modeled as sediment lapping onto 
the flank of the basalt high. Due to the small density contrast of the Waverly Heights basalt and the older volcanics, the Waverly Heights basalt must be surrounded by sediments to allow for sufficient contrast between the two to generate an anomaly of this size. The willamette River is centered in a graben with flood sediments flooring the valley where it crosses the model. The actual structure has been mapped in detail by Beeson and others (1989) and the simplified representation depicted by the block model allows a close fit of the modeled to observed gravity.

The Portland Hills fault is modeled as a vertical fault with 320 meters offset which was required to fit the anomaly. Attempts were made to model the fault as a high angle normal fault but no improvement over the vertical model was observed. The fault is interpreted as offsetting the Waverly Heights basalt due to the steep gravity decrease which is more prominent crossing the high between Oak Grove and Oregon City. Along the east side of the Portland Hills fault is a short wavelength anomaly which coincides with what Trimble (1963) believed to be the paleochannel of the willamette River. Jones (1977) modeled this as an alluvial filled graben with 50 meters offset. The present model did not require any offset because a sediment filled channel was adequate to fit the anomaly.

The Boring vent of Mt. Scott has been previously modeled as a low density feature with a density of $2.3 \mathrm{~g} / \mathrm{cm}^{3}$ 
by Jones (1977) and Perttu (1980). Drill holes penetrating the complete section of Mt. Scott are hosted entirely in basalt. The Bouguer gravity map (see Figure 5) also shows a considerable high of $10 \mathrm{mgals}$ over Mt. Scott. The discrepancy between the observed and modeled gravity over the top of the mountain indicates the vent is filled with lower density, probably pyroclastic, material. This was not included in the model due to the lack of gravity stations to define the vent properly. An additional block 100 meters thick of $2.8 \mathrm{~g} / \mathrm{cm}^{3}$ density material was placed on the Columbia River basalt to increase the gravity under Mt. Scott. The Sandy River Mudstone is encountered in drill holes that penetrating the basalt flows of Mt. Scott. However, they show substantial uplift of the Sandy River Mudstone. The drill holes do not penetrate to the columbia River basalt allowing for only speculation about the actual configuration of the Columbia River basalt below Mt. Scott.

East of Mt. Scott from 153 to $160 \mathrm{~km}$ is a slight gravity low. This required the addition of lighter deposits near the surface and a slight thinning of the Columbia River basalt of about 10 meters.

The Troutdale and the Sandy River formations were modeled as two separate blocks although previous models have considered the two units as one density block. The density measurements made on the Sandy River Mudstone prompted this split. 
The east side of the Portland Basin is modeled as being offset by two faults. The first fault is offset 60 meters. The second fault to the east with 180 meters offset is supported by modeling by Davis (1987) and drill hole data further to the south near cottrel, oregon.

The sediments that are modeled below the Columbia River basalt in the Portland Basin represent arc and fore arc sediments that were filling a topographic low previous to the eruption of the basalt.

\section{Clackamas Heights Model}

The Clackamas Heights line is located northeast of Clackamas Heights and extends along Forsythe Road (Figure 11). The line is located on the terrace between the Clackamas River and Boring vents. This line was surveyed to locate the extension of the Portland Hills fault. The model was kept as simple as possible to prevent the generation of a fault where one may not exist. A $50 \mathrm{~km}$ section of the regional model and gravity profile (Figure 12) shows the gravity rises to 14 mgals and falls back to -25 mgals. This profile crosses the edge of the gravity high generated by the Waverly Heights basalt which is represented as the oak Grove gravity high on the Complete Bouguer Gravity Map (see Figure 5). The detailed portion of the gravity line falls between $142 \mathrm{~km}$ and $144.2 \mathrm{~km}$ on the regional line. This is located over the northeast portion of the gravity high. The 


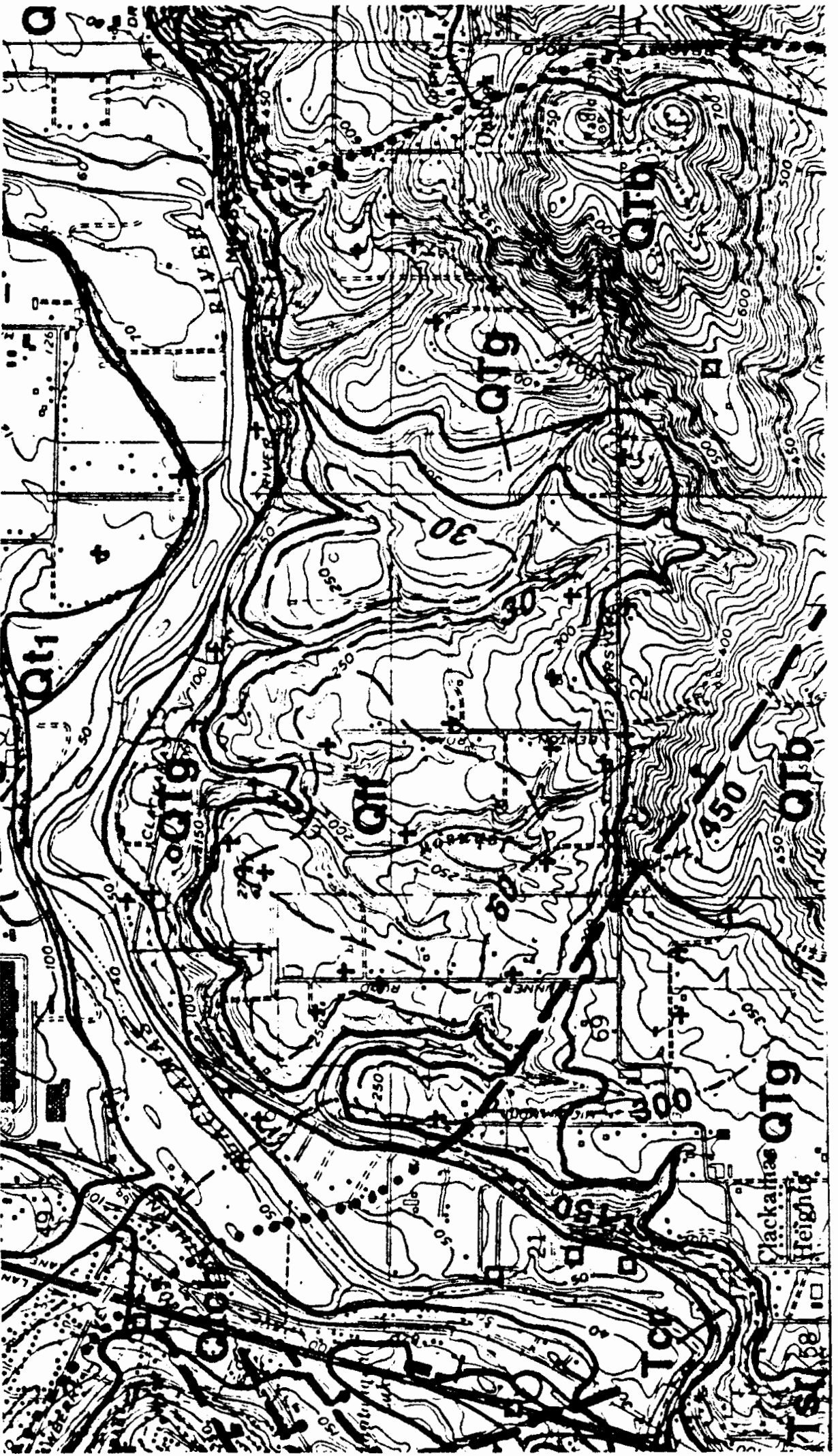

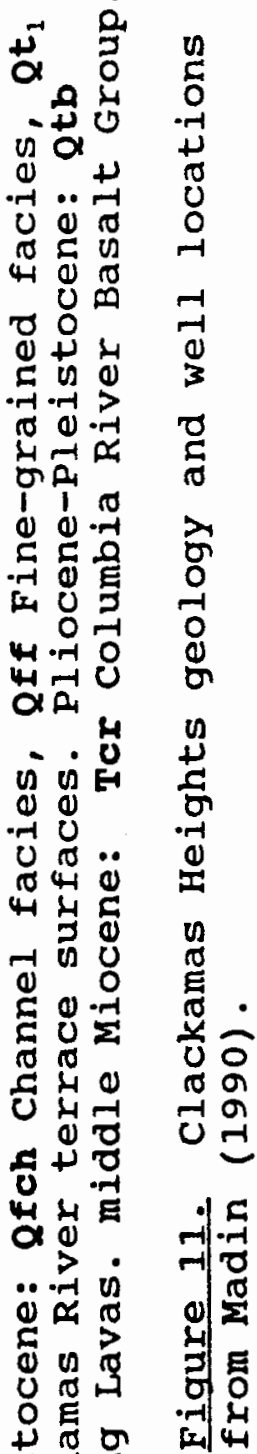

in

- $\begin{aligned} & -1 \\ & 0.7\end{aligned}$

(1) 10

勻它品 


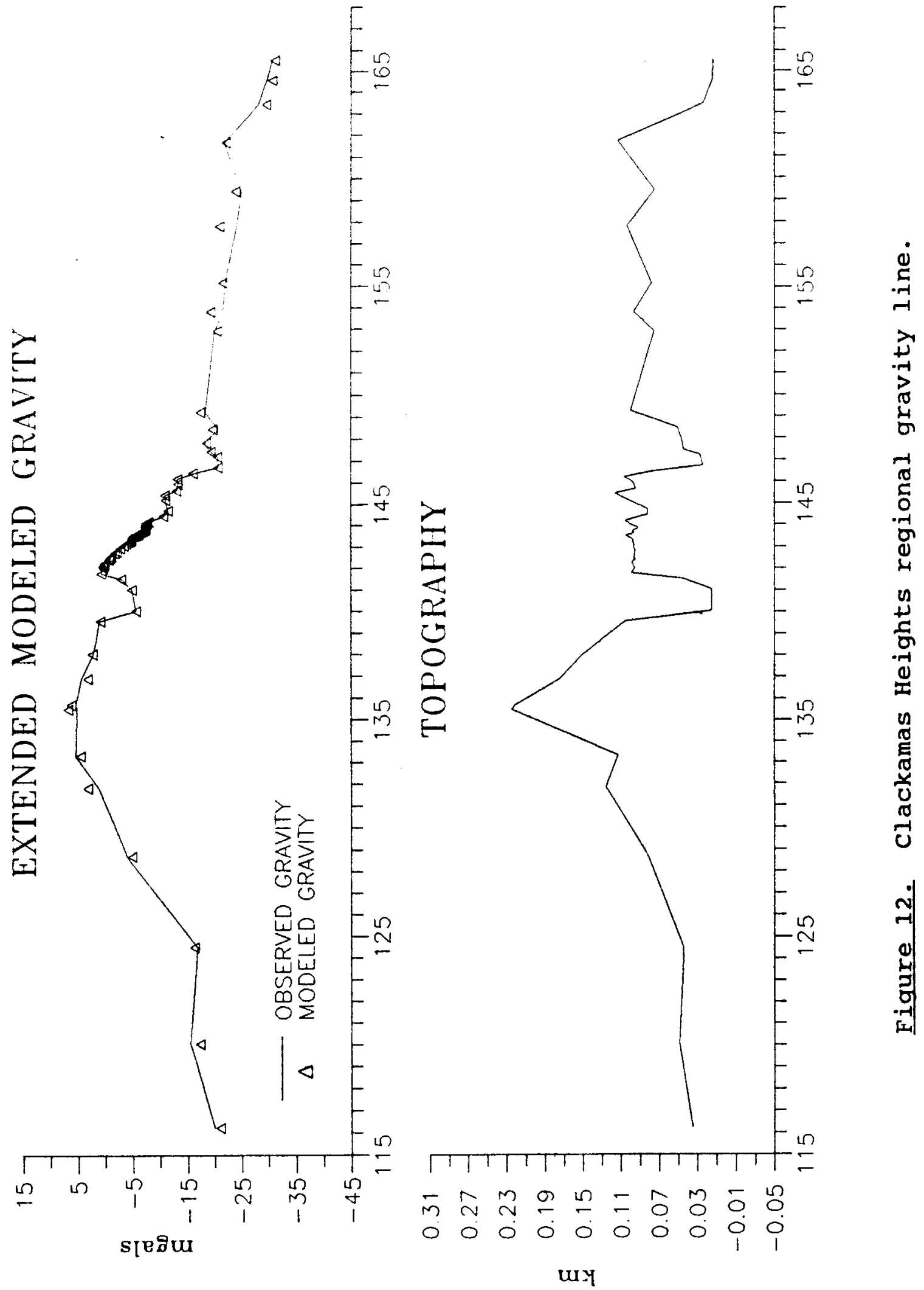


overall character of the line shows the gradual decrease along the detailed segment. The slope of the basalt generating the gravity high is modeled as being at 18 degrees. The amount of sediment between the Waverly Heights basalt and the Columbia River basalt is uncertain. Any change in thickness of the sedimentary wedge only raises or lowers the overall values of the long wavelength gravity without changing the shape.

The Columbia River basalt is modeled in Figure 13 as one consistent block without any offset. The wells along the Clackamas River (see Figure 11) intercept the Columbia River basalt at 10 meters. However, $7 \mathrm{~km}$ northeast near Damascus, oregon, the basalt is intercepted at 182 meters. In the first model (Figure 13) the offset is not included and assumed to fall outside the detailed portion of the line. The constant thickness of the columbia River basalt block has no effect on the short wavelength changes of the line, rather, causes an overall increase in gravity across the entire line. The only short wavelength variations are generated by the high density Boring Lavas which crop out along the surface. The line crosses the toes of these flows causing small anomalies. Water wells penetrating the Boring lava flows (see Figure 11) were used to constrain the size and shape of the blocks inserted into the model which represent the Boring Lavas. The well location are marked by $"+"$ symbols on the map (Figure 11). 


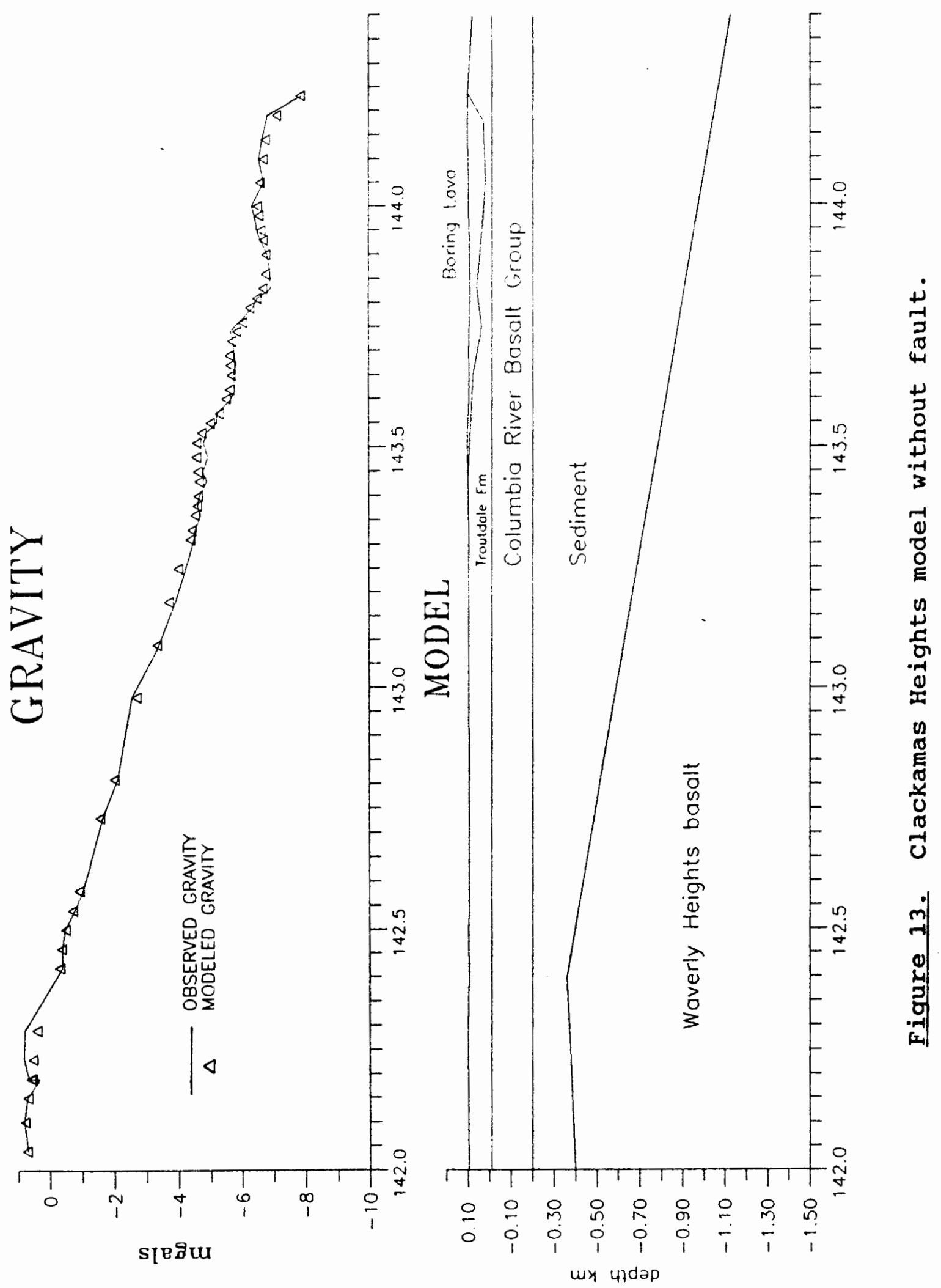


The model shown in Figure 14 indicates a second possibility for the subsurface configuration along the line. The Columbia River basalt as well as the Waverly Heights basalt have been offset 200 meters at the point believed by Madin (1990) to be the location of the Portland Hills Fault. The effect of this configuration is shown by Figure 14 which causes the detailed portion of the line to be offset .3 mgals at the east end and approximately .5 mgals at the west end of the detailed portion of the line. There is only a slight break in slope across the fault zone. The second gravity profile on Figure 15 shows the observed gravity and the modeled gravity coinciding. This was accomplished by simply decreasing the depth to the waverly Heights basalt by 60 meters with a slight angle adjustment. 


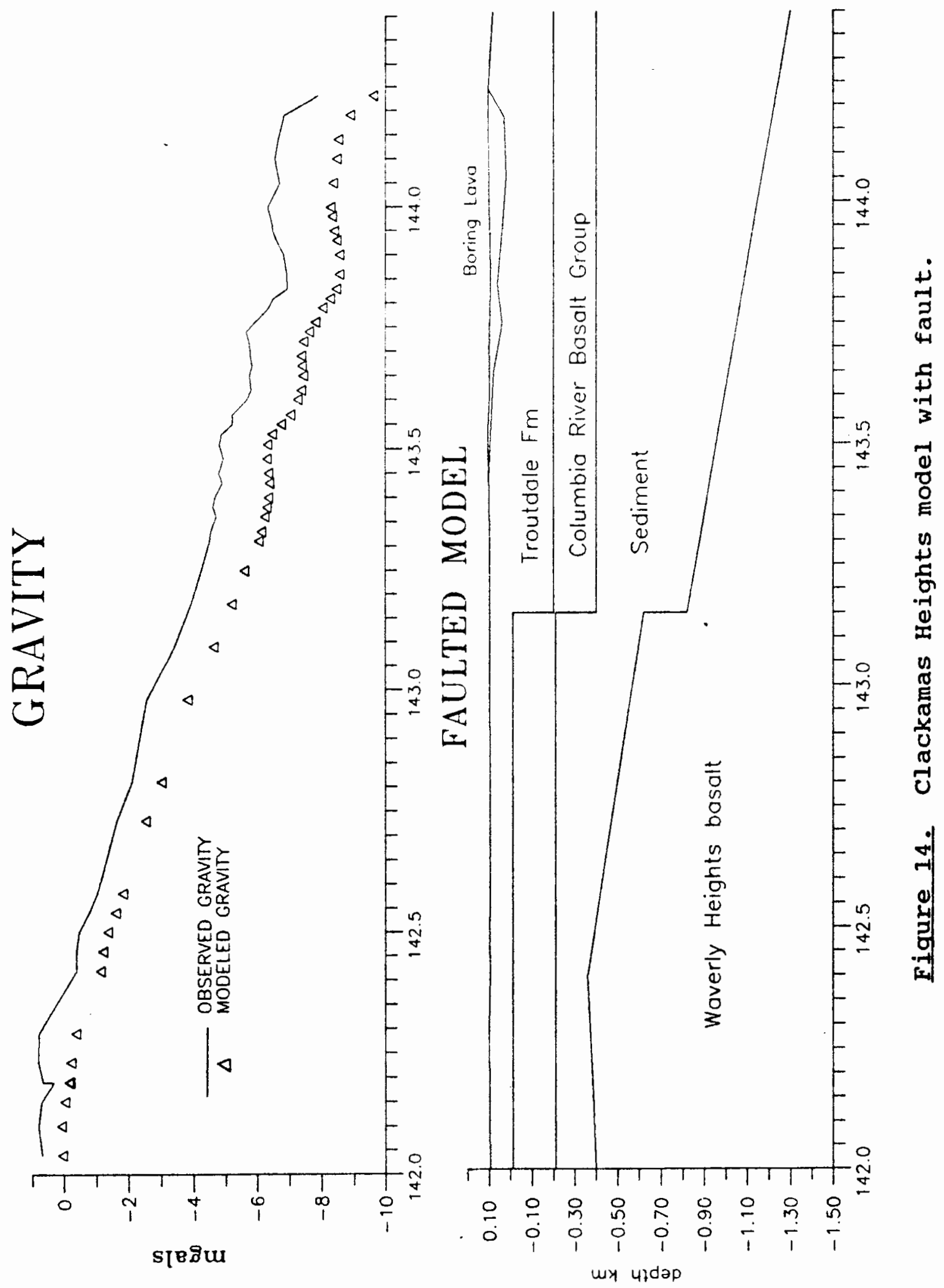




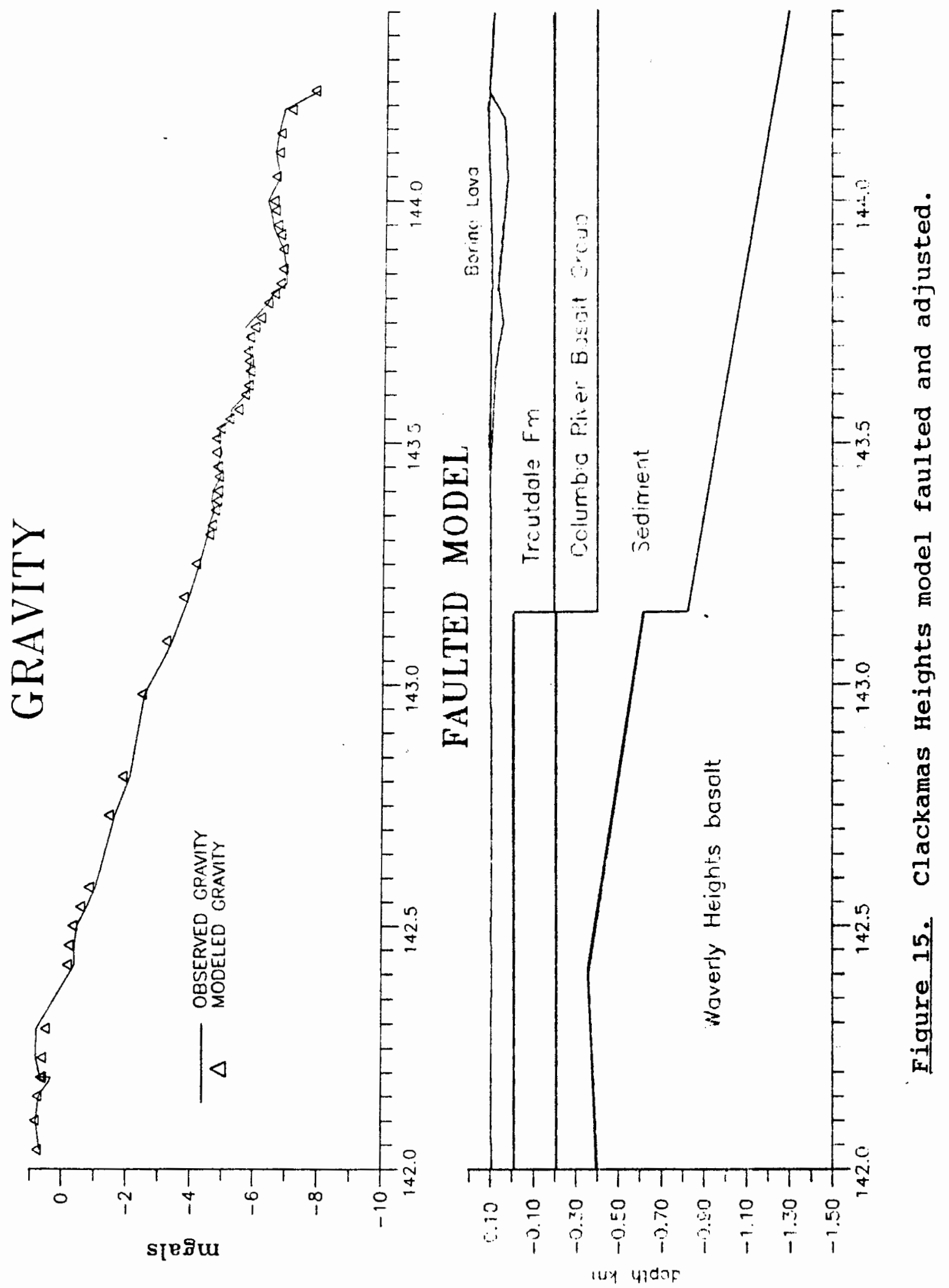




\section{DISCUSSION}

Several prominent features and other smaller anomalies are present on the gravity maps (see Figures $5,7,8$ ). All three maps display a strong north-south alignment of the contours along the western edge of the map. This strong trend is caused by the Coast Range. The complete Bouguer gravity values decrease sharply from $50 \mathrm{mgals}$ at the center of the Coast Range to -30 mgals progressing eastward into the willamette Valley (see Figure 5). The steep gradient bends around the western margin of the Tualatin Valley gravity low which drops to -60 mgals. The high gravity values of the coast Range have been attributed to nearsurface accumulations of high density volcanics that are not in isostatic balance (Thiruvathukal, 1970). This is also shown by the free-air gravity map where the gravity reaches 100 mgals. The decrease in gravity values along the eastern edge of the coast Range represents the strong contrast of the Tillamook Highland against the thick sequence of volcanic/marine sediments of the Tualatin Valley.

The east edge of the Complete Bouguer gravity map also exhibits north-south trending contours which range from -30 mgals at the edge of the willamette Valley to -90 mgals along the east edge of the map. Unlike the coast Range, the 
Cascades are composed of lower density andesitic to dacitic volcanics rather than dense basalt. This large decrease in gravity is caused by the cascades being in isostatic equilibrium. The Cascade Mountains have a root which displaces the mantle with lighter material, creating the gravity low. The gravity decrease may also be caused in part by the transition from predominantly oceanic derived crust, across a transform, to thicker continental type crust.

The Free-air Gravity Map, (see Figure 8) shows two prominent anomalies. These anomalies are the Tualatin Valley gravity low and the Gladstone gravity high which are positioned in a much broader and flatter gravity region which extends around these anomalies. The free-air gravity values generally reflect the uncompensated topography. on the Complete Bouguer Gravity Anomaly Map, (Figure 5) the low gravity anomaly of approximately -35 mgals is centered over Hillsboro, Oregon. This low extends $35 \mathrm{~km}$ north-south and $25 \mathrm{~km}$ east-west and also has a northeast extension. The Iow extends around the north end of the Tualatin Mountains which is shown better by the free-air and residual gravity maps (see Figures 7 and 8 ). Other smaller gravity lows that may be associated with the Tualatin Valley low are found around the prominent gravity high as shown by the free-air gravity map. This may indicate that the marine sediments located below the columbia River basalt in the Tualatin Valley 
actually surround the gravity high, creating this contrast. A thick accumulation of marine sediments below the Tualatin Basin would account for the size of the low. Approximately 3 mgals of the low is caused by the additional fine grained sediments that fill the basin above the columbia River basalt Group.

The second prominent anomaly in the willamette Valley is the gravity high centered over Gladstone, oregon. This 50 mgal high shown by the Bouguer Gravity Map (see Figure 5) tapers off to the north into the Portland Basin and extends southwest toward wilsonville, oregon. The free-air gravity map shows the high to be discontinuous crossing the columbia River to the northeast. This high correlates well with locations where the Waverly Heights basalt crops out. This high was previously attributed and modeled as an intrusion associated with the Boring Lava but is now considered to be a volcanic center formed proximal to the North American plate (Marvin H. Beeson personal communication, 1989). Gravity maps of the Portland Basin were constructed by Perttu (1980) who showed the presence of the gravity highs extending north and northwest into the basin. The features are better defined because of the compilation of all gravity data throughout the area. The noses of higher density material described by Perttu (1980) probably represent a northern extension of the Waverly Heights basalt similar to the high which extends southwest. 
The Residual Gravity Anomaly Map (see Figure 7) reveals that the gravity high extends to the northeast into the Cascades with a greater, yet gradual, drop where it crosses the assumed position of the portland Hills fault. The Portland Basin however, is not well outlined on the residual map. There do appear to be northeast trends that border both sides of the northeast extension of the gravity high. These align with the lineation referred to as the YamhillBonneville Structural Zone (Hammond, 1971).

The small circular gravity anomaly on the northeast flank of the gravity high is created by the dense basaltic lavas which make up Mt. Scott. This gravity high is present on all the gravity maps including the Bouguer Gravity Map indicating that the density of the flows are greater then $2.67 \mathrm{~g} / \mathrm{cm}^{3}$ Bouguer correction factor. Other Boring vents are not represented well on the gravity map due to the lack of gravity stations at these sites.

On the gravity maps, the trend of the portland Hills fault is weak to the north and south of the gravity high. The lack of expression in the gravity values probably caused by the lack of density contrast. The Tualatin Mountains with the east side being faulted into the basin is the surficial expression of the continous layer of basalt being folded and faulted on a surface of low density volcanic sediments. This offset creates a large surficial expression yet the net contrast in density is small, being generated 
only by the variation in densities of the sediments above and below the basalt. Any offset of the sediments below the basalt would have little if any effect on the gravity due to the uniform density. Therefore any offset of the basement would be transparent to gravity surveys. Where the Portland Hills fault crosses the gravity high, the fault probably displaces high density Waverly Heights basalt which creates a large basement density contrast thus making the fault trend more apparent. This alignment of contours defining the position of the Portland Hills fault coincides with the northwest trending linear feature that was described by Perttu (1980) and attributed to the fault. The gravity survey by Schmela (1971) across the probable southeast extension of the Portland Hills fault revealed very small gravity offsets due to the lack of density contrast as well as the predominance of lateral, rather than vertical, fault motion.

The eastern margin of the Portland Basin is defined by the Lackamas lake lineament as well as the decrease in gravity entering into the edge of the Cascade Mountains. Davis (1987) modeled a gravity survey across this Iineament to the north where it is covered by sediments and found the lineament to be show up in the gravity model. South of the Columbia River the zone is not defined by a lineament other than the northwest orientation of the sandy River. Davis (1987) defined the location of the fault using gravity 
modeling along the interstate I-84. The fault modeled by Davis (1987) is substantiated by drill hale data which intercepted the Columbia River basalt at -165 meters below sea level near Cotrell, oregon, along the eastern margin of the basin while east of the Sandy River and along the entire length of the columbia River Gorge the columbia River basalt crops out.

Yelin and Patton (1989) used approximately 30 welllocated earthquakes occurring since 1982 along the Portland Basin margins to calculate fault plane solutions. They note that the earthquakes are not related to the Portland Hills fault, rather the earthquakes were related to the east margin of the basin which they referred to as the Frontal fault zone. The movement calculated is right lateral shear which fits the pull-apart basin model proposed by Beeson and others (1985) and is consistent with the extension modeled by Davis (1987)

Perttu (1980) indicated that there is no expression of a syncline in the gravity values across the Portland Basin although it is reflected in drill hole data. The model from this study results in the same conclusion. The lack of gravity change is similar to the problem with the Tualatin Mountains where the columbia River basalt represents a relatively uniform layer of high density material that can vary in vertical position with little effect on the gravity values, once again appearing transparent. Therefore the 
slight syncline in the basin cannot be detected using gravity surveys.

The Oak Grove line is shown in Figure 16 as modeled by Jones (1977). The model fits the interpretation as the intrusive equivalent of the Boring Lavas. Numerous gravity stations were added and modeled by Perttu (1980) which helped to define the Portland Basin. These models served as the starting point to incorporate recent subsurface data and new interpretations of the Waverly Heights basalt. The earlier modeled intrusion served as the source of the gravity high but does not fit the field evidence showing the correspondence of the gravity high with the 40 Ma Waverly Heights basalt surrounded by younger sediments. This information allowed the basalt to be modeled as part of the higher density basement with sediments filling around the high. However, there is little difference between models of the gravity high other than the actual shape of the dense block and increased detail across the Portland Basin. This demonstrates the fact that while there is not a unique model for any gravity profile, models can be constrained by addition of actual subsurface configurations and densities. The Clackamas Heights line was intended to locate the Portland Hills fault with enough precision to enable further study by trenching. This survey was unsuccessful in this regard, however the results show that the contrast in density is not large enough, considering the depth to the 


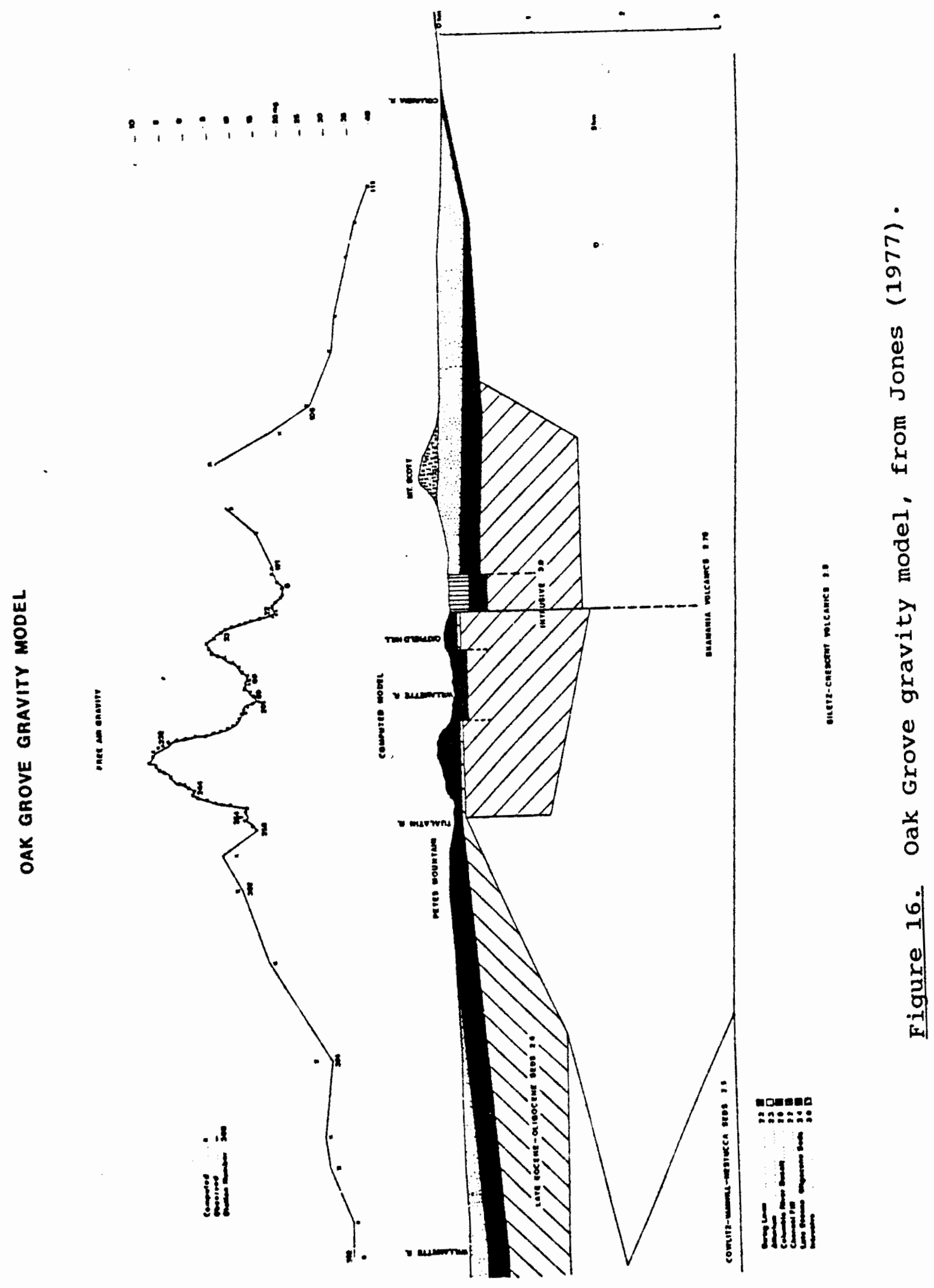


structure, to produce an anomaly that is recognizable as being uniquely created by the fault. If the basement configuration could be constrained at one end of the line the survey may reveal more information.

The Clackamas Heights line shows where the Boring Lavas are crossed by the gravity line even though the flows are covered by weathering products and alluvium. The gravity values indicate that the high created by the waverly Heights basalt extends to the southeast past the clackamas Heights area and the decrease in values shows the high is decreasing in thickness in this direction.

The Portland and Tualatin basins and associated smaller anomalies occur within the broad region of the northern willamette Valley. The Portland Basin has recently been a focus of attention. The Portland Basin was termed a pullapart basin by Beeson and others (1985) due to the shape which was referred to as " highly suggestive of a pull-apart basin tectonically related to wrench faulting ". The tectonics generating the basin as well as the structural and sedimentary evidence were not included or supported by further discussion. The Portland Basin is situated within an active stress regime which favors the formation of wrench or strike-slip type basins.

The orientation and position of the Portland Hills fault, Gales Creek fault and the Frontal fault appear to be an extension of the strike-slip faults that terminate the 
Basin and Range extension in southeastern oregon (Figure 17). The faults that terminate the basin and range are comprised of many smaller faults. The Brothers and the Sisters fault zone along with the Eugene-Denio zone and McLoughlin fault zone are all comprised of many smaller faults rather than one primary fault (Lawrence, 1976). The Brothers fault zone trend of north 60 degrees west deflects to north 35 degrees west near Bend, oregon (Lawrence, 1976). The portion of the fault zone north of Bend, oregon is informally referred to as the sisters fault zone. The Sisters fault zone is in perfect alignment with the Portland Hills-Clackamas trend which is also orientated north 35 degrees west. The fractures in the Brothers fault zone are en echelon in pattern, however the sisters fault zone is made up of parallel fractures (Lawrence, 1976). The Gales creek fault, along with the Portland Hills and Frontal fault zones are all parallel, which is consistent with the sisters fault zone. Lawrence (1976) stated that the Brothers fault zone appeared to merge with the eastern depression of the High Cascade Depression. The Sisters fault zone appears to extend beneath the Cascade Range into the Portland area where the parallel faulting at north 35 degrees west orientation is continued.

Lawrence (1976) notes that the Brothers fault zone is in rocks less than $6 \mathrm{Ma}$. Beeson and others (1989) have demonstrated that a barrier causing the Columbia River 


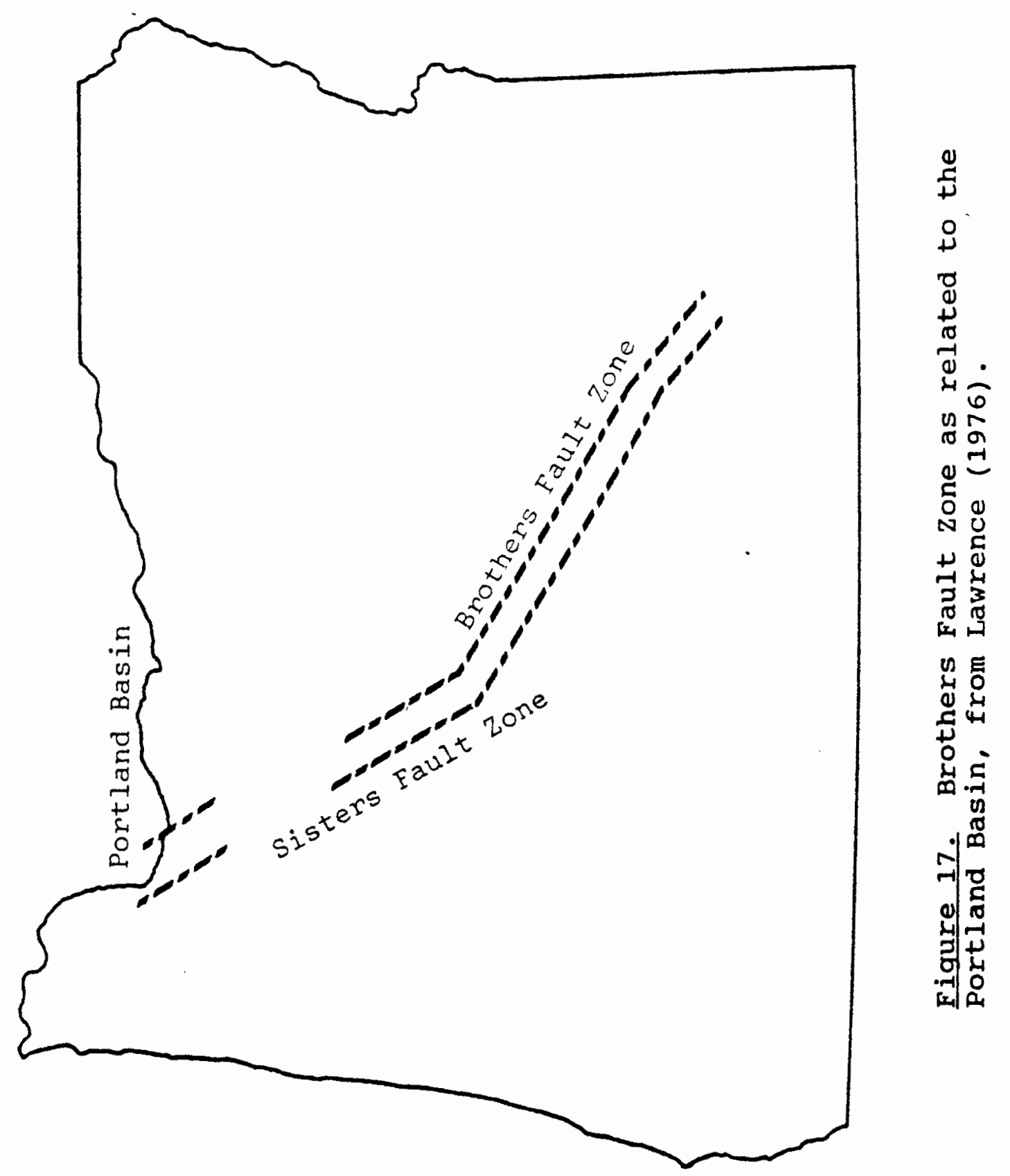


basalt to thin from 500 meters east to 100 meters west of the Portland Hills-Clackamas river structural zone redirected the Grande Ronde flows at $15.6 \mathrm{Ma}$. Yelin and Patton (1989) determined the Frontal fault zone to be active indicating that this zone of faulting has been active for millions of years and continues to be active.

It is therefore my assumption that the Portland HillsClackamas River structural zone is an extension of the Sisters fault zone with dextral motion. The following discussion substantiates this assumption.

The greater Portland area is crossed by three parallel northwest trending faults which border the Portland and Tualatin basins. The Frontal fault zone (Yelin and Patton, 1989) along the eastern margin of the Portland Basin, the Portland Hills fault along the west edge of the Portland Basin, and the Gales Creek fault along the west edge of the Tualatin Basin (Figure 18).

The strike-slip motion of the Portland Hills fault is inferred from motion along the Clackamas River zone because the fault is not exposed along the Tualatin Mountains. The lack of lateral offset of the gravity high (see Figure 5) indicates that this fault is a normal fault or a dip-slip fault with a small component of strike-slip. The Portland Hills fault may adjust for differential rates of slip between the Gales creek fault and the Frontal fault caused by the Waverly Heights basalt acting as an anchor. The 


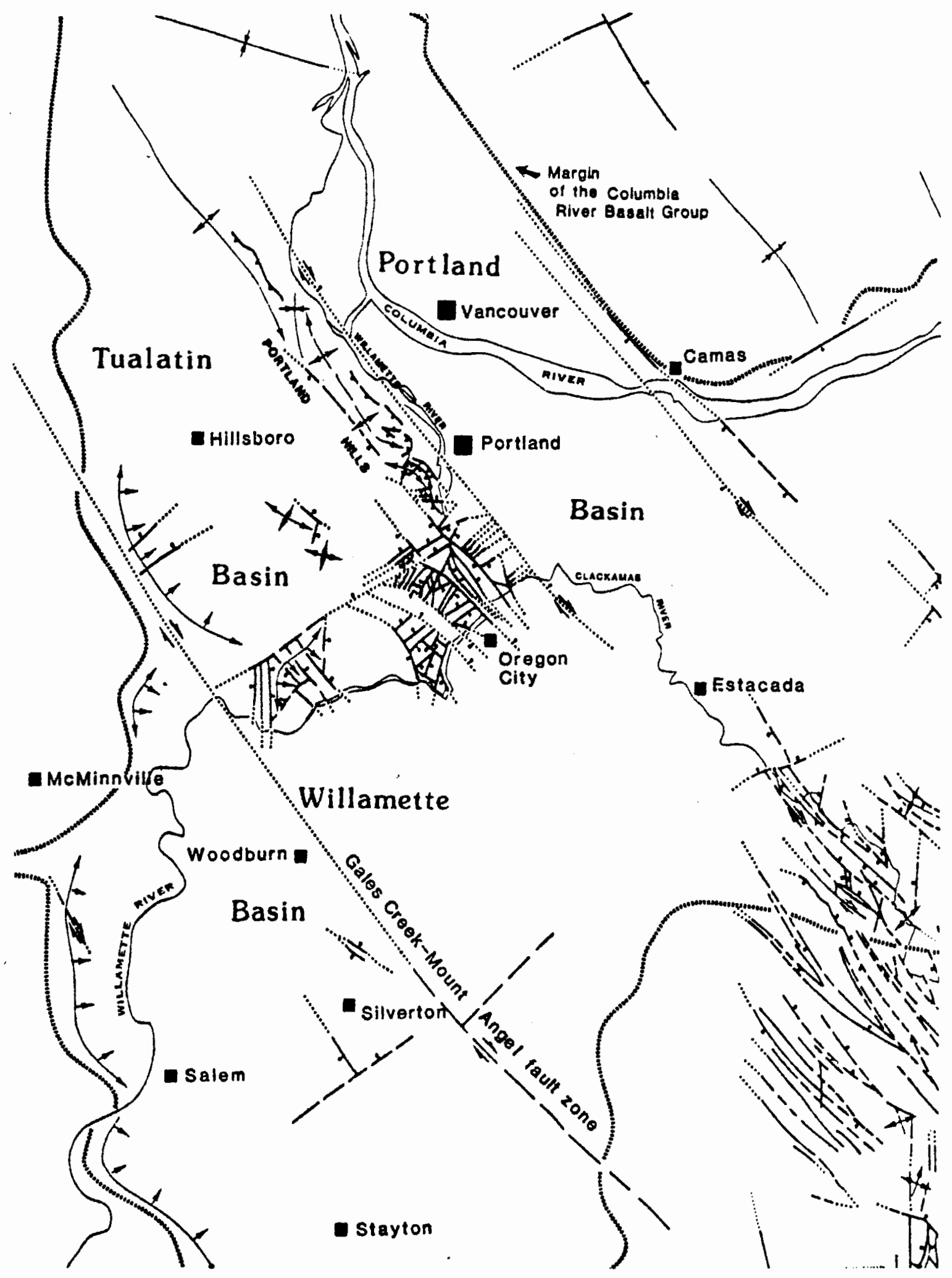

Figure 18. Tectonic map of the greater Portland area from Tolan and others (1989). 
Waverly Heights basalt being $40 \mathrm{Ma}$ is built on of the older oceanic crust. This is surrounded by sediments and covered by Miocene basalt. The Waverly Heights basaltic high

allowed less movement to occur and caused the basalt moving toward it to be compressed while the area to the southwest to be extended (Marvin H. Beeson personal communication, 1990). The Tualatin Mountains are a result of Columbia River basalt movement being restricted by the waverly Heights basalt. The Tualatin Basin has probably experienced rotation of segments of the Columbia River Basalt which has resulted in small pop-ups along faults within the basin (Figure 19). Cooper Mountain and Bull Mountain are east west highs of Columbia River basalt probably created by rotation of the blocks in the basin.

The Portland Basin has the shape of a pull-apart basin or rhomb graben formed by strike-slip motion. Terms related to strike-slip deformation, basin formation and sedimentation were compiled from many authors into a glossary by Biddle and Nicholas Christie-Blick (1985). A pull-apart basin is defined as a basin formed by crustal extension at a release bend or releasing overstep along a strike-slip fault zone and is considered synonymous with rhomb graben. A strike-slip basin is any basin in which sedimentation is accompanied by significant strike-slip motion. These definitions are different from those listed in the Glossary of Geology by Bates and Jackson (1987). 


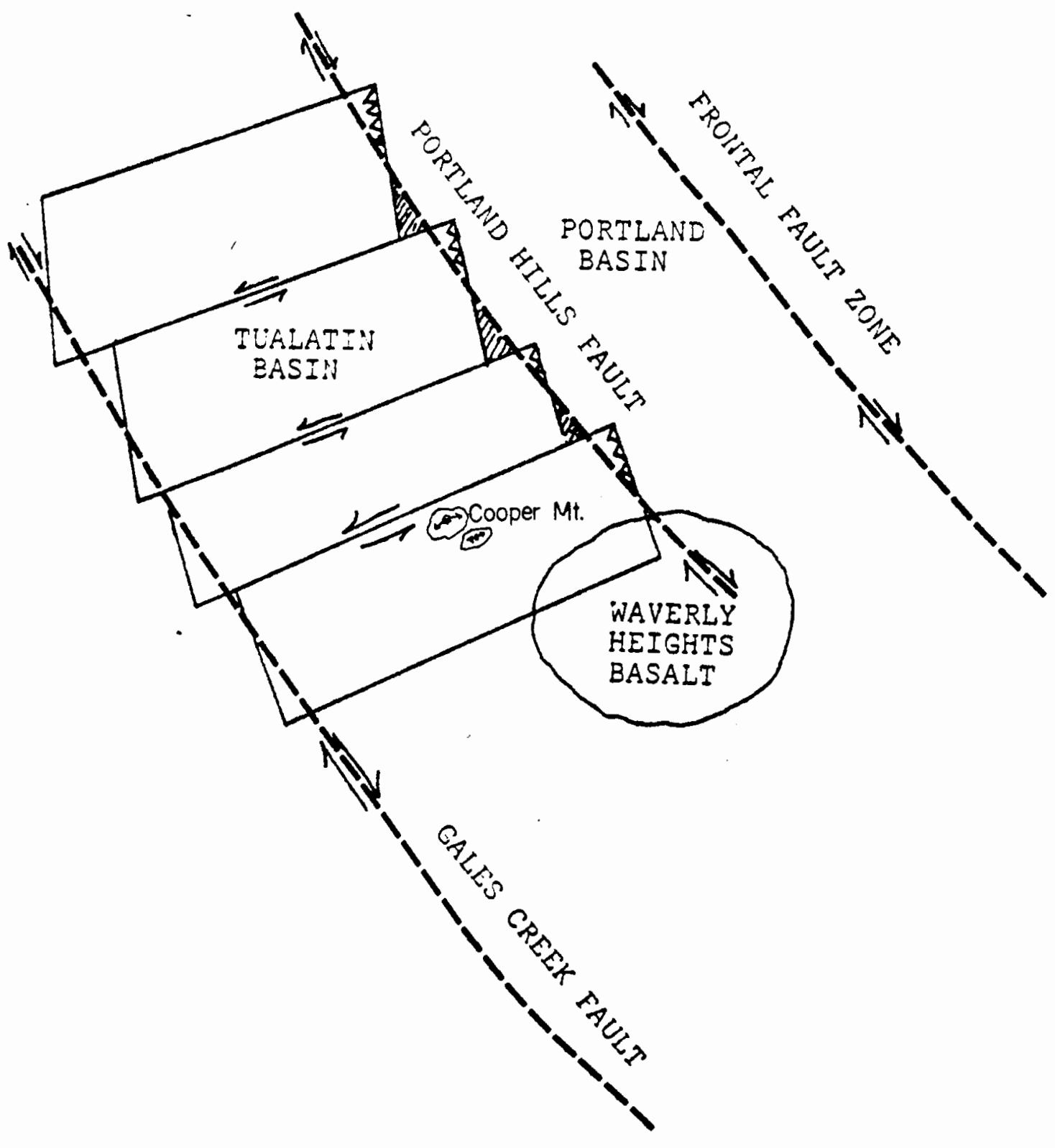

Figure 19. Portland area structural interpretation. 
There are many variations in forms of basins caused by geologic variability and the terminology used to describe these basins are not consistent despite efforts to refine the definitions.

other authors have described special attributes for pull-apart basins which were noted in different study areas, mostly being in California. Aydin and Nur (1982) noted that pull-apart basins often exhibit elongated lakes and sag ponds, often containing young sedimentary deposits, and often involve volcanic and geothermal activity. They note that one fairly consistent feature is the length to width characteristics of 3:1 (Aydin and Nur, 1982). Bahat (1983) states that many rhomb structures considered to be "welldefined " by Aydin and Nur (1982) are misleading, and that fault boundaries are inferred rather than being carefully mapped along with the strike-slip mechanism, which is also uncertain. The Portland Basin is also defined by its shape but the faults bounding the basin are not traceable on the surface so their extent is uncertain. Hempton and Neher (1986) modeled strike-slip faults in a claybox and noted an extremely complicated zone with fractures, strain, and subsidence patterns that developed in the clay. "The fracture pattern is more complex than predicted by theoretical models..." (Hempton and Neher, 1986). This is probably analogous to the Portland Basin where the displacement is spread over a zone rather than one main 
strike-slip fault.

Gravity surveys across a pull-apart or strike-slip basin would be represented by one of two possible configurations. Crowell and Link (1982) describe the Ridge Basin in California as having $13 \mathrm{~km}$ of sediment accumulation in 7 million years, and Yeats (1978) notes the Ventura Basin subsided nearly $4 \mathrm{~km}$ in the past 1 million years. The gravity profiles across these basins would show as gravity lows. The second possibility would be a gravity high if there have been intrusions from the mantle. Fuis and others (1984) believe this to be the case in the Imperial Valley Region, California, where the Salton Trough is actually a gravity high rather than a low due to the mafic intrusive rock filling the space between the sediments and the basement. The Mortagne pluton in France probably formed in this manner (Guineberteau and others, 1987). The granitic pluton was emplaced as an underlying layer in a pull-apart void formed by transcurrent movement along the Armorican Shear Zone (Guineberteau and others, 1987). The map showing depth to the pluton floor derived from the gravity map shows the rhomb shape well. The edges of the Portland Basin are not represented well on gravity maps. This probably indicates that the rate of movement and sediment accumulation along the faults is much slower than in California. 


\section{CONCLUSIONS}

Gravity modeling in this study has confirmed that the gravity high is correctly interpreted by Beeson and others (1989) as an older basalt high rather than an intrusion associated with the Boring Lavas. Mt. Scott is composed of predominantly basaltic lavas which creates a small high gravity anomaly on the flank of the large anomaly created by the waverly Heights basalt. The gravity high is offset 320 meters by the Portland Hills fault with a sediment filled channel along the down-dropped side. Below the down-dropped Columbia River basalt in the Portland Basin are sediments filling around the waverly Heights basalt high which thickens to the northeast. The eastern margin is faulted near the Sandy River.

The gravity maps of the greater Portland area show more detail than the large scale Complete Bouguer Gravity Anomaly Map of Oregon produced by Berg and Thiruvathukal (1967). The Tualatin Basin is a gravity low caused by a thick accumulation of sediments below the columbia River basalt and sediments filling the depression above the basalt. The gravity high near oak Grove is caused by the waverly Heights basalt which crops out in the area of the gravity high. 
The Clackamas Heights survey shows that the area is located above the sloping edge of the gravity high. The thickness of Boring Lavas in the area is consistent with modeled values. 100 meters of terrace deposits obscure the Portland Hills fault. More subsurface control might have constrained the model sufficiently to enable placement of the fault.

The Portland area is crossed by a zone of parallel strike-slip faulting that extends from the sisters fault zone, which is the northern extension of the Brothers fault zone. The strike-slip motion is generating the Portland and Tualatin basins with small pop-ups in the Tualatin Basin caused by block rotation. The gravity maps indicate that the Portland Basin is developing slower and in a different style than classical pull-apart basins being formed in California.

Gravity stations are needed to define the gravity high perpendicular to the oak Grove gravity line and in the Portland Metropolitan area west of the willamette River. The eastern margin of the Portland Basin requires more stations to define the edge. The area along the columbia River from Troutdale to $25 \mathrm{~km}$ east and $20 \mathrm{~km}$ on both sides of the river needs to be defined with more gravity stations. 


\section{REFERENCES CITED}

Aydin, A., and Nur, A., 1982, Evolution of pull-apart basins and their scale independence: Tectonics, v. 1, p. 91105.

Allen, J.R., 1975, Volcanoes of the Portland area, Oregon: Ore Bin, v. 37, no. 9, p. 145-157.

Anderson, J.L., 1978, Structure and stratigraphy of the Columbia River Basalt Group in the Clackamas River Drainage: M.S. thesis (unpublished), Portland state University, Portland, Oregon.

Bahat, D., 1983, New aspects of rhomb structures: Journal of Structural Geology, v. 5, p. 591-601.

Balsillie, J.H., and Benson, G.T., 1971, Evidence for the Portland Hills Fault: The ore Bin, v. 33, no. 6, p. 109-118.

Bates, R.L., and Jackson, J.A., 1987, Glossary of Geology (3rd edition): Alexandria, Virginia, American Geological Institute, $788 \mathrm{p}$.

Beaulieu, J.D., 1971, Geologic formations of western oregon: oregon Department of Geology and Mineral Industries Bulletin, v. 70, 72 p.

Beeson, M,H., Bentley, R.D., and Moran, M.R., 1976, Preliminary correlation of lower Yakima Basalt flows in western oregon with the type area in central washington (abs): 72nd Annual Meeting, Cordilleran Section, Geological Society of America.

Beeson, M.H., Fecht, K.R., Reidel, S.P., and Tolan, T.L., 1985, Regional correlations within the Frenchman Springs Member of the Columbia River Basalt Group: New insights into the middle Miocene tectonics of Northwestern Oregon: Oregon Department of Geology and Mineral Industries, oregon Geology, v. 47, no. 8, p. 87-96. 
Beeson, M.H., Johnson, A.G., and Moran, M.R., 1975, Portland Environmental Geology - Fault Identification: final technical report, U.S. Geological survey contract no. 14-08-0001-14832, Geology Department, Portland state University, Portland, Oregon.

Beeson, M.H., and Nelson, D.O., 1978, A model for the geologic history of Mt. Tabor, Kelly Butte, and Powell Butte in SE Portland: Proceedings of the oregon Academy of Science, v. 14, p. 142-143.

Beeson, M.H., and Tolan, T.L., 1988, The Columbia River Basalt Group in the Cascade Range: A Middle Miocene reference datum for structural analysis: Proceedings of workshop XIIV geological, geophysical, and tectonic setting of the Cascade Range, open-file report 89-178, p. 257-290.

Beeson, M.H., Tolan, T.L., and Anderson, J.L., 1989, The Columbia River Basalt Group in western Oregon; Geologic structures and other factors that controlled flow emplacement patterns: Geological society of America Special Paper 239, p. 223-245.

Beeson, M.H., Tolan, T.L., and Madin, I.P., 1989, Geologic Map of the Lake Oswego Quadrangle, Clackamas, Multnomah, and Washington Counties, Oregon: Oregon Department of Geology and Mineral Industries, Geologic Map Series, GMS-59.

Berg, J.W., Jr., and Thiruvathukal, J.V., 1967, Complete Bouguer Gravity Anomaly Map of oregon: oregon Department of Geology and Mineral Industries, Geologic Map Series, GMS-11

Biddle, K.T., and Christie-Blick, N., 1985, Glossary strike-slip deformation, basin formation, and sedimentation, in Biddle, K.T., and Christie-Blick, N., eds., strike-slip deformation, basin formation, and sedimentation: Society of Economic Paleontologists and Mineralogists special publication 37, p. 375-385.

Bromery, R.W., and Snavely, P.D., Jr., 1964, Geologic interpretation of reconnaissance gravity and aeromagnetic surveys in northwestern Oregon: United states Geological Survey Bulletin 1181-N.

Crowel1, J.C., and Link, M.H., eds., 1982, Geologic history of the Ridge basin, southern California: society of Economic Paleontologists and Mineralogists, Pacific section, Guidebook, $304 \mathrm{p}$. 
Davis. S.A., 1987, An analysis of the eastern margin of the Portland Basin using gravity surveys: M.S. thesis (unpublished), Portland State University, Portland, oregon.

Dobrin, M.B., 1960, Introduction to geophysical prospecting: New York, McGraw Hill Book Company; 1976, 3rd ed., $446 \mathrm{p}$.

Fassio, J.M., 1990, Geochemical evolution of ferruginous bauxites in northwestern oregon and southwestern Washington: M.S. thesis (unpublished), Portland state University, Portland, Oregon.

Fuis, G.S., Mooney, W.D., Healy, J.H., McMechan, G.A., and Lutter, W.J., 1984, A seismic refraction survey of the Imperial Valley Region, California: Journal of Geophysical Research, v. 89, n. B2, p. 1165-1189.

Guineberteau B., Bouchez, J., and Vigneresse, J., 1987, The Mortagne granite pluton (France) emplaced by pull-apart along a shear zone: Structural and gravimetric arguments and regional implication: Geological society of America Bulletin, v. 99, p. 763-770.

Hempton, M.R., and Neher, K., 1986, Experimental fracture, strain and subsidence patterns over en echelon strikeslip faults: Implications for the structural evolution of pull-apart basins: Journal of Structural Geology, v. 8, p. 596-605.

Hodge, E.T., 1938, Geology of the lower Columbia River: Geological Society of America Bulletin, v. 49, no. 6, p. $831-930$.

Jones, T.D., 1977, Analysis of a gravity traverse south of Portland, Oregon: B.S. thesis (unpublished), Portland State University, Portland, Oregon.

Lawrence, R.D., 1976, Strike-slip faulting terminates the Basin and Range province in oregon: Geological Society of America Bulletin, v. 87, p. 846-850.

Lentz, R.T. 1981, The petrology and stratigraphy of the Portland Hills Silt-a Pacific Northwest loess: Oregon Geology, v. 43, no. 1, p. 3-10.

Madin, I.P., 1990, Earthquake-hazard geology maps of the Portland Metropolitan Area, Oregon: Oregon Department of Geology and Mineral Industries open File Report o90-2. 
McFarland, W.D., 1983, A description of aquifer units in western oregon: U.S. Geological Survey Open File Report $82-165$.

Newton, V.C., Jr., 1969, Subsurface Geology of the lower Columbia and Willamette Basins, oregon: Oregon Department of Geology and Mineral Industries, oil and Gas Investigation, no. 2, 121 p.

Perttu, J.D., 1980, An analysis of gravity surveys in the Portland Basin, Oregon: M.S. thesis (unpublished), Portland State University, Portland, Oregon.

Perttu, R.K., 1976, structural geology of the northeast quarter of the Dutchman Butte quadrangle, oregon: M.S. thesis (unpublished), Portland State University, Portland, Oregon.

Phillips, w.M., Walsh, T.J., and Hagen, R.A., 1988, Eocene transition from oceanic to arc volcanism, southwest Washington: Proceedings of workshop XLIV geological, geophysical, and tectonic setting of the Cascade Range, open-file report 89-178, p. 199-240.

Schmela, R.J., 1971, Geophysical and geological analysis of a fault-like linearity in the Lower clackamas River Area, Clackamas county, oregon: M.S. thesis Portland State University, Portland, Oregon.

Simpson, R.W., and Cox, A.V., 1977, Paleomagnetic evidence for tectonic rotation of the oregon coast Range: Geology, v. 5, p. 585-589.

Swanson, R.D., 1986, A stratigraphic and geochemical study of the Troutdale Formation and Sandy River mudstone in the Portland Basin and lower Columbia River Gorge: M.S. thesis (unpublished), Portland State University, Portland, oregon, $151 \mathrm{p}$.

Talwani, M., Lamar, W., Landisman, M., 1959, Rapid gravity computations for two-dimensional bodies with

application to the Mendocino submarine Fracture zone: Journal of Geophysical Research, v. 64, no. 1, p. 4959 .

Telford, W.M., Geldart, L.P., Sheriff, R.S., and Keys, D.A., 1976, Applied geophysics: Cambridge, Cambridge University Press, $860 \mathrm{p}$.

Thiruvathukal, J.V., Berg, J.W., Jr., and Heinrichs, D.F., 1970, Regional Gravity of oregon: Geological Society of America Bulletin, v. 81, p. 725-738. 
Tolan, T.L., 1989, Geologic map of the Portland area: (unpublished).

Tolan, T.L., 1982, The stratigraphic relationships of the Columbia River Basalt Group in the lower Columbia River Gorge of Oregon and Washington: M.S. thesis (unpublished), Portland State University, Portland, Oregon, $151 \mathrm{p}$.

Tolan, T.L., and Beeson, M.H., 1984, Intracanyon flows of the Columbia River Basalt Group in the lower Columbia River Gorge and their relationship to the Troutdale Formation: Geological Society of America Bulletin, v. 95 , no. 4 , p. 463-477.

Treasher, R.C. 1942, Geologic history of the Portland Area: oregon Department of Geology and Mineral Industries Short Paper no. 7, 17 p.

Trimble, D.E., 1963, Geology of Portland, Oregon and adjacent areas: U.S. Geological Survey Bulletin 1119, $119 \mathrm{p}$.

Waitt, R.B., 1985, Case for periodic, colossal jokulhlaups from Pleistocene glacial Lake Missoula: Geological Society of America Bulletin, v. 96, no. 10, p. 12711286.

Winchell, H., 1938, A new micropycnometer for the determination of densities of heavy solids: American Mineralogist, v. 23, p. 805-810.

Yeats, R.S., 1978, Neogene acceleration of subsidence rates southern California: Geology, v. 6, p. 456-460.

Yelin, T.S., and Patton H.J., 1989, Seismotectonics of the Portland, Oregon Region: EOS, October 24, 1989, p. 1330 . 


\section{APPENDIX}

Constants taken from Telford (1976).

Conversion from latitude in degrees to radians.

$$
\text { radians }=\text { latitude } \mathrm{x} .017453293
$$

Constants for the calculation of theoretical gravity. Equatorial gravity $=978031.8 \mathrm{mgals}$

$$
\begin{aligned}
& \text { alpha }=0.0053024 \\
& \text { beta }=-0.0000058
\end{aligned}
$$

Constants for the calculation of free air and Bouguer gravity.

Free air correction $=-0.3085 \mathrm{mgal} / \mathrm{m}$

Bouguer correction $=0.112 \mathrm{mgal} / \mathrm{m}$

Theoretical gravity $=978031.8 \times(1+.0053024 \times$ $\left.(\sin (\text { latitude }))^{2}\right)-0.0000058 \times(\sin (2 \times$ latitude) ${ }^{2}$ ) Free air gravity = observed gravity theoretical gravity $+0.3085 \mathrm{x}$ elevation

Complete Bouguer gravity $=$ Observed gravity $+(0.3085 \mathrm{x}$

$$
\begin{aligned}
& \text { elevation) - theoretical gravity - }(0.112 \mathrm{x} \\
& \text { elevation) + terrain correction }
\end{aligned}
$$


$\infty>1$

至

\section{足}

.

国

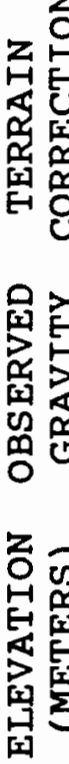

$0+\pi N$ N

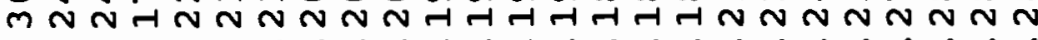

IN $\infty N 00$ ก

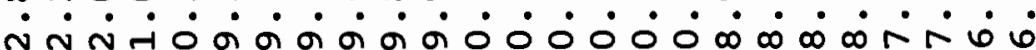
N $N$ N $N$ H

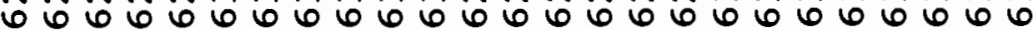

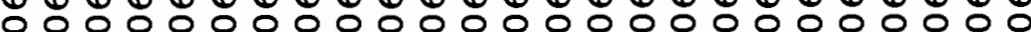

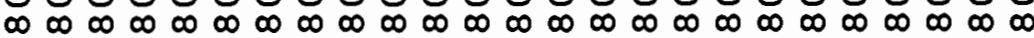

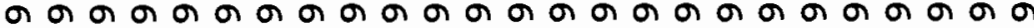

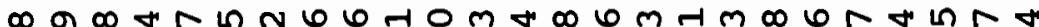

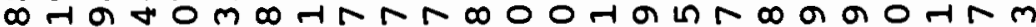

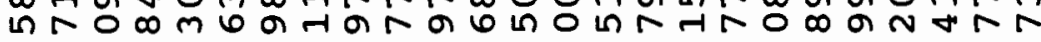
$\dot{0} \dot{0} \dot{0} \cdot \dot{0} \dot{0} \dot{0} \dot{0} \dot{0} \dot{0} \dot{0} \dot{0} \dot{0} \dot{0} \dot{0} \dot{0}$

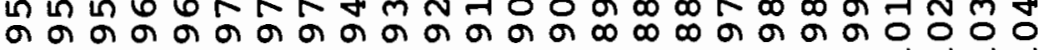
개

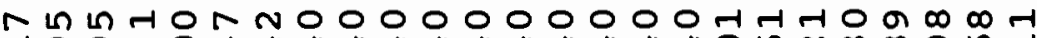
न

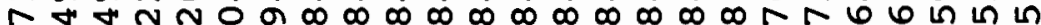

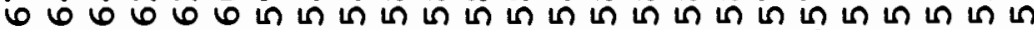
ก

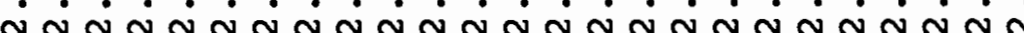

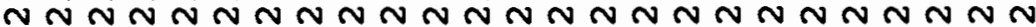

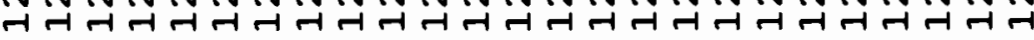

A0

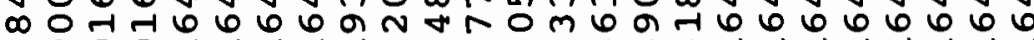

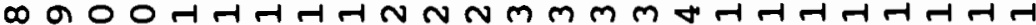

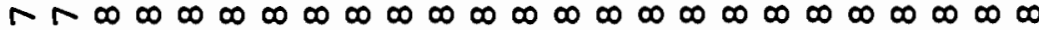
$m m m M m m M m M M m M M m M M m M M M M M M M M$ $\cdot \cdot \cdot \cdot \cdot \cdot \cdot \cdot \cdot \cdot \cdot \cdot \cdot \cdot \cdot \cdot \cdot \cdot \cdot \cdot \cdot \cdot \cdot \cdot$

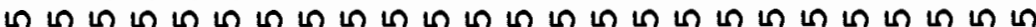

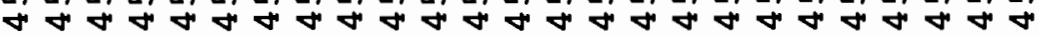

थี is

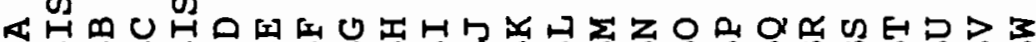
ต 


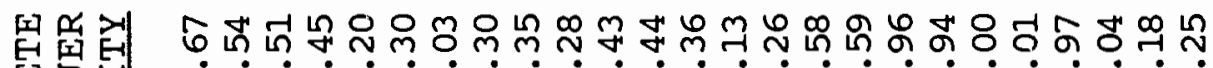
ம்

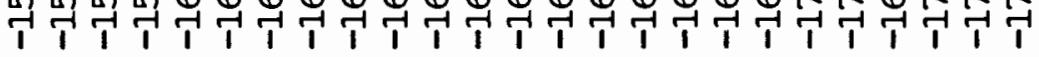

号

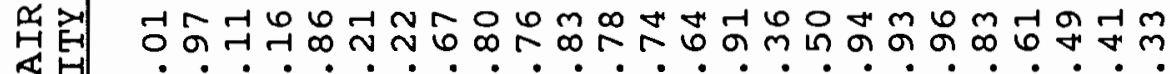

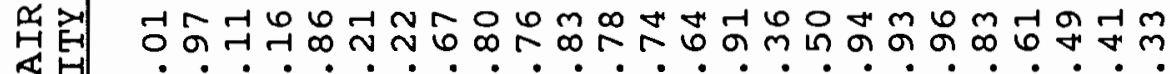

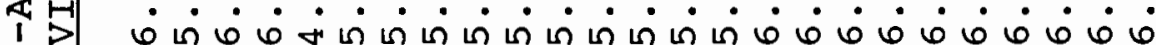

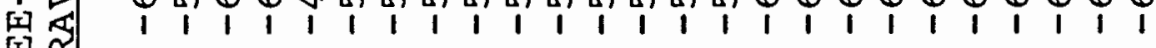

承

된 영

䍃

舫

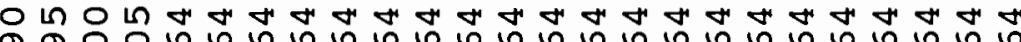
. . . . . . . . $m m \nleftarrow \forall m m m m m m m m m m m m m m m m m m m m m$ เ 6606606066606066060606660 $\circ 000000000000000000000000$

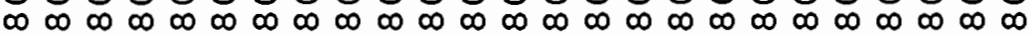

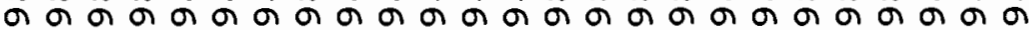

焉

N

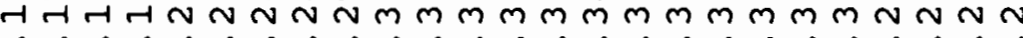

In 0 HO roL $\infty$ R

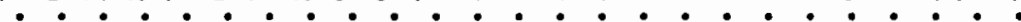
O HA N $N$ N

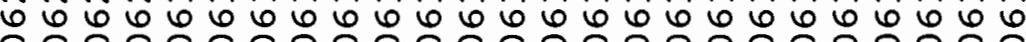

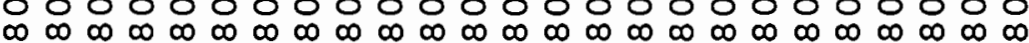

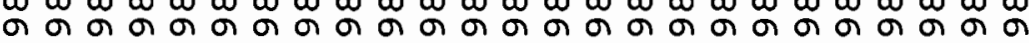

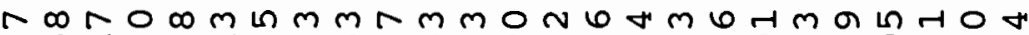
* a

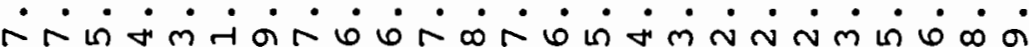
$\infty \infty \infty \infty \circ \sigma a$ \%

$00000 \mathrm{~d}$ a H 4 H

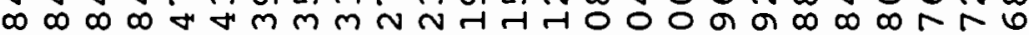
ا in 1 in $\dot{\sim} \dot{\sim} \dot{\sim} \dot{\sim} \dot{\sim} \dot{\sim} \dot{\sim} \dot{\sim} \dot{\sim} \dot{\sim} \dot{\sim} \dot{\sim} \dot{\sim} \dot{\sim} \dot{\sim} \dot{\sim} \dot{\sim} \dot{\sim} \dot{\sim} \dot{\sim}$ N

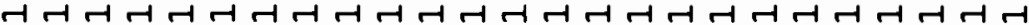

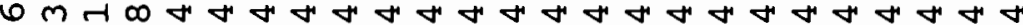

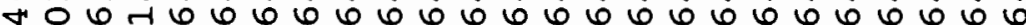
४

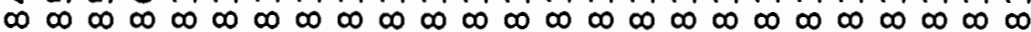
$m m m m m m m m m m m m m m m m m m m m m m m m m$

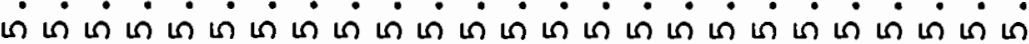

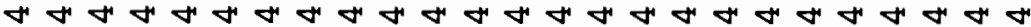

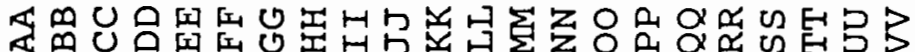
×

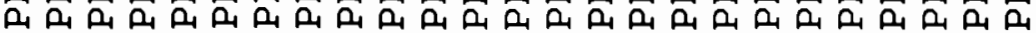




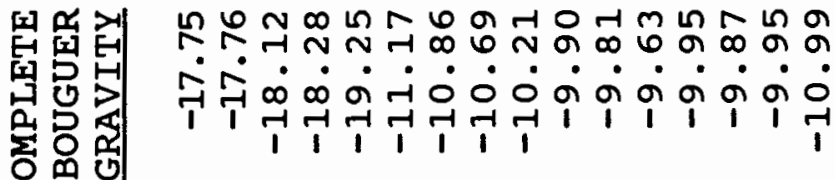

on $\ln$ momanno N

A $2 \pi$ a $06060 \mathrm{mmMNHAO}$ $\dot{m} \dot{m} \dot{m} \dot{m} \dot{m} \dot{m} \dot{m} \dot{m} \dot{m} \dot{m} \dot{m} \dot{m}$ in in in in in in in in in in

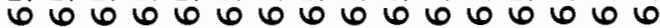
0000000000000000

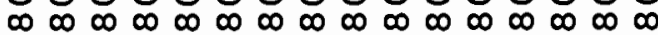

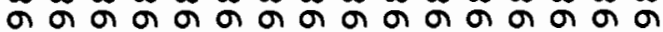

$m N m$ M 100000000000 $N N N N N M M M M M M M M M M$

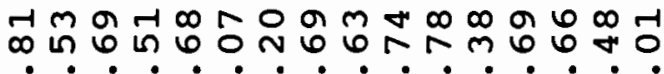
$\dot{1} \dot{1} \dot{\dot{y}} \dot{m} \dot{m} \dot{m} \dot{m} \dot{m} \dot{m} \dot{m} \dot{m} \dot{m}$

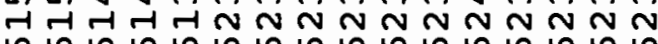

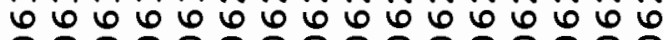

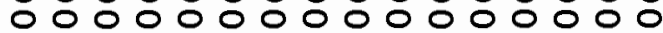
$\begin{array}{llllllllllllllll} & \infty & \infty & \infty & \infty & \infty & \infty & \infty & \infty & \infty & \infty & \infty & \infty & \infty & \infty & \infty\end{array}$

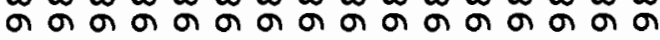

N $66 N \infty 0 m$ \% $\infty N 6$ \% $\dot{0} \dot{0} \dot{0} \dot{0} \dot{0} \dot{0} \dot{0} \dot{0} \dot{0} \dot{0} \dot{0}$

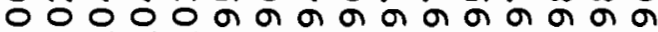
ती $\rightarrow$ -

I on $N$ a 0 in $\rightarrow$ N $N$ क H แ เก เก $\dot{\sim} \dot{\sim} \dot{\sim} \dot{\sim} \dot{\sim} \dot{\sim} \dot{\sim} \dot{\sim} \dot{\sim} \dot{\sim} \dot{\sim}$

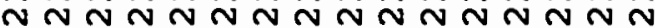

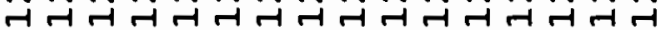

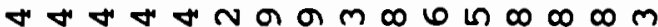

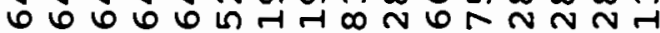
- -1 H $\infty \infty \infty \infty \infty N N N N N N N$ $m m m m m m m m m m m m m m m$ ம் ம் ம் ம் ம்

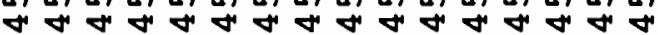

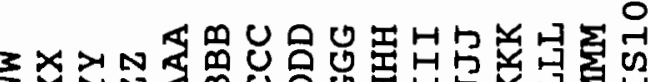

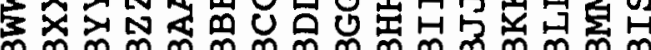

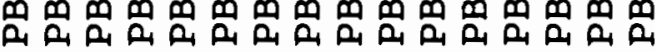

